\title{
Validating Savings Claims of Cold Climate Zero Energy Ready Homes
}

J. Williamson and S. Puttagunta

Consortium for Advanced Residential Buildings 


\section{NOTICE}

This report was prepared as an account of work sponsored by an agency of the United States government. Neither the United States government nor any agency thereof, nor any of their employees, subcontractors, or affiliated partners makes any warranty, express or implied, or assumes any legal liability or responsibility for the accuracy, completeness, or usefulness of any information, apparatus, product, or process disclosed, or represents that its use would not infringe privately owned rights. Reference herein to any specific commercial product, process, or service by trade name, trademark, manufacturer, or otherwise does not necessarily constitute or imply its endorsement, recommendation, or favoring by the United States government or any agency thereof. The views and opinions of authors expressed herein do not necessarily state or reflect those of the United States government or any agency thereof.

Available electronically at http://www.osti.gov/bridge

Available for a processing fee to U.S. Department of Energy and its contractors, in paper, from:

U.S. Department of Energy

Office of Scientific and Technical Information

P.O. Box 62

Oak Ridge, TN 37831-0062

phone: 865.576.8401

fax: 865.576 .5728

email: mailto:reports@adonis.osti.gov

Available for sale to the public, in paper, from:

U.S. Department of Commerce

National Technical Information Service

5285 Port Royal Road

Springfield, VA 22161

phone: 800.553 .6847

fax: 703.605.6900

email: orders@ntis.fedworld.gov

online ordering: http://www.ntis.gov/ordering.htm 


\title{
Validating Savings Claims of Cold Climate Zero Energy Ready Homes
}

\author{
Prepared for: \\ The National Renewable Energy Laboratory \\ On behalf of the U.S. Department of Energy's Building America Program \\ Office of Energy Efficiency and Renewable Energy \\ 15013 Denver West Parkway \\ Golden, CO 80401 \\ NREL Contract No. DE-AC36-08GO28308 \\ Prepared by: \\ J. Williamson and S. Puttagunta \\ Steven Winter Associates, Inc. \\ of the \\ Consortium for Advanced Residential Buildings (CARB) \\ 61 Washington Street \\ Norwalk, CT 06854 \\ NREL Technical Monitor: Stacey Rothgeb \\ Prepared under Subcontract No. KNDJ-0-40342-05
}

June 2015 
The work presented in this report does not represent performance of any product relative to regulated minimum efficiency requirements.

The laboratory and/or field sites used for this work are not certified rating test facilities. The conditions and methods under which products were characterized for this work differ from standard rating conditions, as described.

Because the methods and conditions differ, the reported results are not comparable to rated product performance and should only be used to estimate performance under the measured conditions. 


\section{Contents}

List of Figures

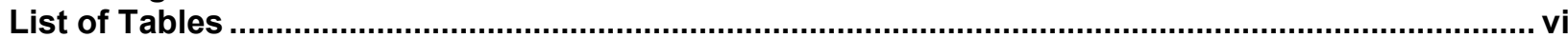

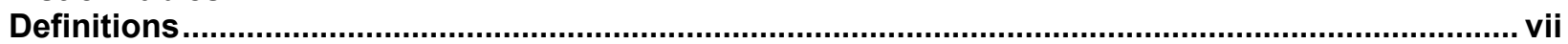

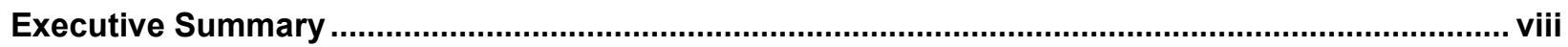

1 Introduction

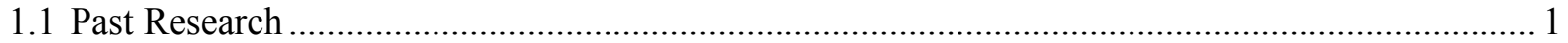

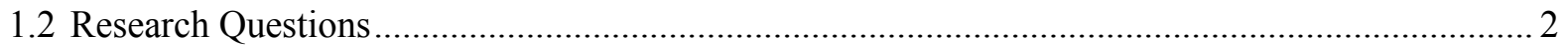

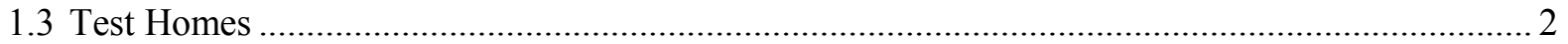

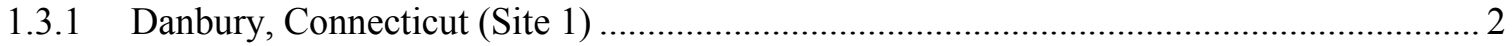

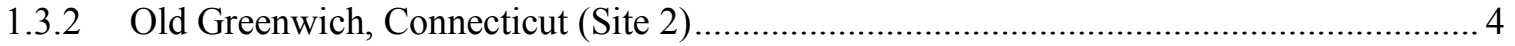

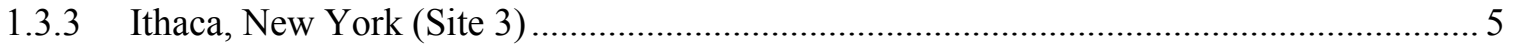

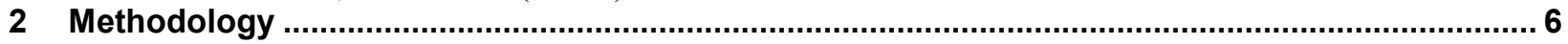

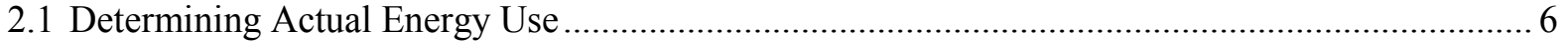

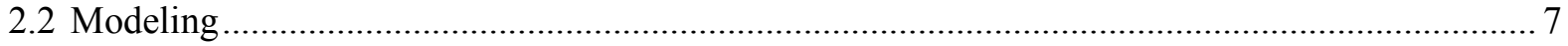

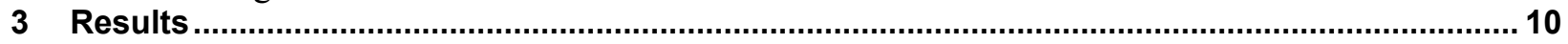

3.1 Annual Comparison of Monitored Versus Modeled Use........................................................ 10

3.2 Monthly Comparison of Monitored Versus Modeled Use......................................................... 11

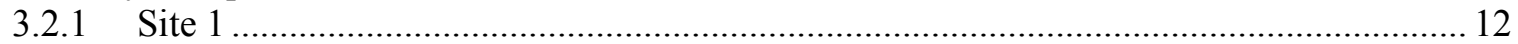

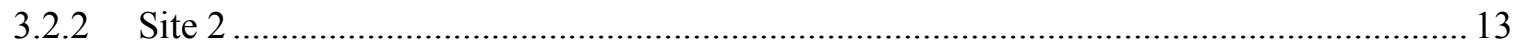

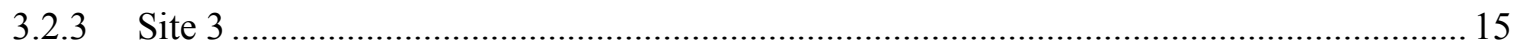

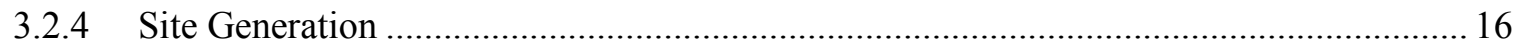

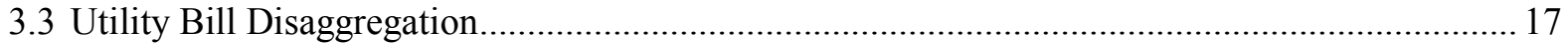

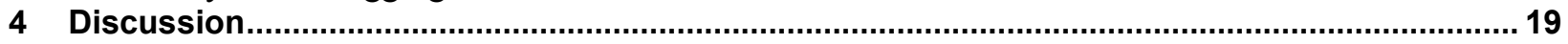

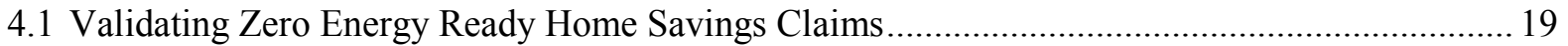

4.2 Adjusting Zero Energy Ready Home Models in BEopt .......................................................... 19

4.2.1 Lights, Appliances, and Miscellaneous Electricity Loads ............................................ 19

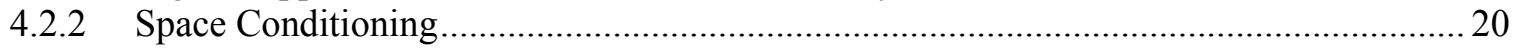

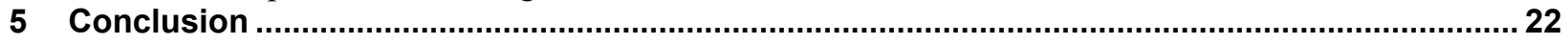

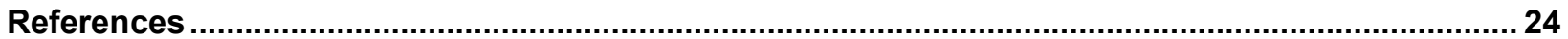




\section{List of Figures}

Figure 1. (Left) Photo of Danbury, Connecticut, home; (Right) ZERH HERS index certificate ........... 3 Figure 2. (Left) Photo of Old Greenwich, Connecticut, home; (Right) ZERH HERS index certificate 4 Figure 3. (Left) Photo of Ithaca, New York, home; (Right) ZERH HERS index certificate .................. 5 Figure 4. Circuit monitoring at Danbury, Connecticut, home ...................................................... 6 Figure 5. Site 1: Total monthly electricity use-measured versus modeled ..................................11 Figure 6. Site 2: Total monthly electricity use-measured versus modeled ...................................11

Figure 7. Site 3: Total monthly electricity use-measured versus modeled ..................................12

Figure 8. Site 1: Monthly electricity end use-measured versus modeled........................................ 13

Figure 9. Site 2: Monthly electricity end use-measured versus modeled........................................ 14

Figure 10. Site 2: Monthly gas end use-measured versus modeled ........................................... 15

Figure 11. Site 3: Monthly electricity end use-measured versus modeled........................................16

Figure 12. Utility bill disaggregation of non-space-conditioning loads ......................................... 17

Figure 13. Utility bill disaggregation of space-conditioning loads ................................................ 18

Figure 14. Site 1: Daily average mini-split heat pump consumption comparison .......................... 21

Unless otherwise noted, all figures were created by CARB.

\section{List of Tables}

Table 1. Summary of Modeled Versus Actual Site Energy Total Consumption (Excluding Photovoltaics)

Table 2. Electric Site Energy Consumption Comparison Summary: Percent Difference Between

Measured and Modeled ix

Table 3. Danbury, Connecticut, Building Specifications ...

Table 4. Old Greenwich, Connecticut, Building Specifications ................................................. 4

Table 5. Ithaca, New York, Building Specifications ...................................................................... 5

Table 6. Relationship Between Number of Bedrooms and Number of Occupants ............................. 8

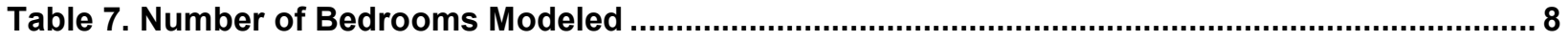

Table 8. Average Indoor Temperatures During Monitoring Period................................................. 9

Table 9. Difference in Weather Data Between Monitoring Period and TMY3 Data ............................. 9

Table 10. Summary of Modeled Versus Actual Energy Consumption (Excluding PV) .................... 10

Table 11. Electricity Site Energy Consumption Comparison Summary: Percent Difference

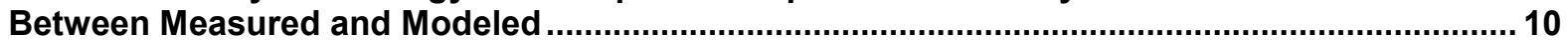

Table 12. PV Generation: Modeled Versus Measured .................................................................... 16

Table 13. Site Energy: Model Prediction Compared to Actual Use (Excluding PV) .......................... 19

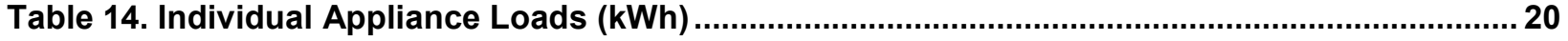

Table 15. Site Energy: Model Prediction Compared to Actual Use (Excluding PV)........................ 22

Table 16. Electrical Energy Consumption Comparison Summary: Percent Difference in Site Energy Use Between Measured and Modeled.

Unless otherwise noted, all tables were created by CARB. 


\section{Definitions}

$\mathrm{ACH}$

BA

BEopt $^{\mathrm{TM}}$

CARB

DHW

DOE

ERV

HDD

HERS

IECC

$\mathrm{kWh}$

LAMEL

PV

$\mathrm{RH}$

TMY3

ZERH
Air Changes per Hour

Building America

Building Energy Optimization (software)

Consortium of Advanced Residential Buildings

Domestic Hot Water

U.S. Department of Energy

Energy Recovery Ventilator

Heating Degree Day

Home Energy Rating System

International Energy Conservation Code

Kilowatt-hour

Lights, Appliances, and Miscellaneous Electricity Load

Photovoltaic

Relative Humidity

Typical Metrological Year ( $3^{\text {rd }}$ version $)$

Zero Energy Ready Home 


\section{Executive Summary}

The U.S. Department of Energy's (DOE's) Zero Energy Ready Home (ZERH) program (formerly DOE Challenge Home) has resulted in more than 14,000 energy-efficient homes since its inception in 2008. Each ZERH is verified by a third-party energy rater, achieves at least $40 \%$ energy savings compared to a 2006 International Energy Conservation Code (IECC) minimum built home, and typically scores a Home Energy Rating System (HERS) Index of 55 or lower. ZERHs are also designed to provide superior air quality, water efficiency, comfort, and resiliency.

DOE's Building America research team Consortium for Advanced Residential Buildings (CARB) has been helping builders and developers achieve ZERH certification in various climate zones across the country since its inception (DOE 2013a,b; DOE 2014a,b,c,d,e).

This study was intended to validate actual performance of three ZERHs in the Northeast to energy models created in REM/Rate v14.5 (one of the certified software programs used to generate a HERS Index) and the National Renewable Energy Laboratory's Building Energy Optimization (BEopt ${ }^{\mathrm{TM}}$ ) v2.3 E+ (a more sophisticated hourly energy simulation software).

This report details the validation methods used to analyze energy consumption at each home. It includes a detailed end-use examination of consumption from the following categories:

- Heating

- Cooling

- Lights, Appliances, and Miscellaneous Electricity Loads (LAMELs) along with Domestic Hot Water Use

- Ventilation

- Photovoltaic Generation.

All data are presented in terms of site energy consumption because this energy metric is used to calculate the HERS Index used in the ZERH certification process. A utility bill disaggregation analysis, which allows a crude estimation of space-conditioning loads based on outdoor air temperature, was also performed; the results were compared to the actual measured data.

For this study, the actual measured site energy consumption was no more than $5 \%$ greater than the model estimates. The authors sought to ensure that the estimated energy savings compared to the 2006 IECC reference model were not grossly overestimated. A conservative energy-savings claim does not diminish the value of the program.

At first glance, the results in Table 1 are encouraging because the overall estimated savings for these three homes was $-4 \%$ or lower than the adjusted REM/Rate savings based on actual use. These results provide some confidence that estimated energy-savings goals from ZERH projects were achieved or exceeded. Further analysis shows that total consumption was fairly in line for the two units that weren't Passive Homes; however, end-use loads revealed several significant discrepancies at all three sites. 
Table 1. Summary of Modeled Versus Actual Site Energy Total Consumption (Excluding Photovoltaics)

\begin{tabular}{c|c|c|c}
\hline $\begin{array}{c}\text { Site Energy } \\
\text { (MBtu/year) }\end{array}$ & Site 1 & Site 2 & Site 3 \\
\hline Estimated REM/Rate Savings & $65 \%$ & $58 \%$ & $44 \%$ \\
\hline Actual Measured Data & 33.4 & 88.6 & 16.4 \\
REM/Rate Model Estimates & 31.5 & 84.8 & 27.8 \\
\hline REM/Rate \% Difference & $6.0 \%$ & $4.5 \%$ & $-41.0 \%$ \\
Base BEopt Model Estimates & 32.4 & 91.3 & 29.4 \\
\hline Base BEopt \% Difference & $3.1 \%$ & $-3.0 \%$ & $-44.2 \%$ \\
\hline Tuned BEopt Model Estimates & 32.7 & 87 & 24.1 \\
\hline Tuned BEopt \% Difference & $2.1 \%$ & $1.8 \%$ & $-32.0 \%$ \\
\hline Adjusted REM/Rate Savings & $61 \%$ & $55 \%$ & $62 \%$ \\
\hline
\end{tabular}

Table 2 shows that differences varied from site to site but discrepancies in the LAMEL category had the greatest impact on the total estimates. Much of this discrepancy stems from the fact that LAMELs are most dependent on occupant usage trends. Also, heating, cooling, and hot water loads are much lower for low-load homes so the LAMELs comprise a greater percentage of total energy use. Except for the Site 1 REM/Rate model, actual measured LAMELs were 13\%-57\% lower than estimated by the models. Modeling assumptions are based on the typical homeowner but ZERH occupants may be more energy conscious than the typical homeowner. CARB evaluated whether a miscellaneous load reduction factor should be used for ZERHs; however, a larger sample size is needed to develop a meaningful figure. If known, models should be adjusted to reflect the true number of occupants rather than the number of bedrooms.

Table 2. Electric Site Energy Consumption Comparison Summary: Percent Difference Between Measured and Modeled

\begin{tabular}{c|c|c|c|c|c|c|c|c|c}
\hline & \multicolumn{3}{|c|}{ Site 1 } & \multicolumn{3}{c|}{ Site 2 } & \multicolumn{3}{c}{ Site 3 } \\
\hline Model & REM/ & Base & Tuned & REM/ & Base & Tuned & REM/ & Base & Tuned \\
Rate & BEopt & BEopt & Rate & BEopt & BEopt & Rate & BEopt & BEopt \\
Heating & $98 \%$ & $96 \%$ & $109 \%$ & $74 \%$ & $262 \%$ & $290 \%$ & $-29 \%$ & $66 \%$ & $41 \%$ \\
$\begin{array}{c}\text { Cooling } \\
\text { LAMELs } \\
\begin{array}{c}\text { and } \\
\text { Domestic }\end{array}\end{array}$ & $-29 \%$ & $85 \%$ & $57 \%$ & $150 \%$ & $178 \%$ & $61 \%$ & - & - & - \\
$\begin{array}{c}\text { Hot Water } \\
\text { Total }\end{array}$ & $10 \%$ & $-13 \%$ & $-13 \%$ & $-34 \%$ & $-32 \%$ & $-32 \%$ & $-45 \%$ & $-57 \%$ & $-45 \%$ \\
\hline
\end{tabular}

${ }^{a}$ For Site 2 the heating fuel is natural gas so only fan energy is accounted for in this analysis.

${ }^{\mathrm{b}}$ Sites 1 and 2 are showing only LAMELs because Site 1 uses propane for DHW and Site 2 uses natural gas. 


\section{Introduction}

The U.S. Department of Energy's (DOE) Zero Energy Ready Home (ZERH) program includes a set of design and construction principles that are used to achieve a building energy and performance standard. (See the program website in references: "Zero Energy Ready Home" undated.) Buildings that meet the standard are predicted to use at least $40 \%$ less energy than a typical new 2006 International Energy Conservation Code (IECC) code-compliant home of equivalent size. The ZERH label is marketed as a symbol for excellence among new homes. Achieving higher energy performance is just one of the many benefits of the program, which recognizes builders and developers for their exceptional projects. This recognition helps to spur ongoing market transformation. Third-party verification of the home performance is an often overlooked component but is of particular value to the homebuyers because it ensures that they are purchasing a high-quality product. By incorporating countless best practices developed under the Building America (BA) program ("Building America Solutions Center" undated), future home occupants also benefit from improved indoor air quality, enhanced durability, and increased comfort. However, this program is relatively new so field validation related to the projected performance and energy savings is lacking. Performance validation data are desirable to justify the added investment needed to incorporate the design specifications into future projects.

The goal of this initial study was to examine actual end-use consumption in three ZERHs in the Northeast (cold climate) compared to energy modeling predictions. The evaluation involved comparing the field monitoring of circuit-level electrical energy consumption versus the predicted energy use as calculated in REM/Rate v14.5 (one of the certified software packages used to generate a Home Energy Rating System [HERS] Index) and the National Renewable Energy Laboratory's Building Energy Optimization (BEopt ${ }^{\mathrm{TM}}$ ) v2.3 E+ (a more sophisticated hourly energy simulation software). This field monitoring was supplemented with a utility bill disaggregation of the research homes. If estimates are accurate, documentation of actual performance enhances the program knowledge base, reinforces the program benefits, and provides compelling reasons for participating in the program. If estimates are inaccurate, issues with energy modeling techniques for ZERHs would be identified.

\subsection{Past Research}

Researchers at Washington State University (part of the Building America Partnership for Improved Residential Construction research team) examined a year of utility bills from a Passive House in Hood River, Oregon (marine climate), and compared the data to modeling predictions made in BEopt 1.2 E+. The modeled home predicted a total site energy use of 7,144 kWh/year with Typical Meteorological Year 3 (TMY3) heating degree days at base $65^{\circ} \mathrm{F}$ (HDD65) of 5,499 . This equates to energy savings of $68 \%$ compared to the IECC 2009 benchmark home. More than $47 \%$ of the annual modeled load is attributed to miscellaneous electricity loads. Utility bills from a 361-day monitoring period that accumulated 4,102 HDD65 show consumption of $4,939 \mathrm{kWh}$. With modeling, predictions show that only $2.3 \%$ of the total annual consumption comes from heating loads. This indicates that the mild monitoring period likely would not have had a drastic effect on the total consumption. Thus, a major conclusion of the study was that the comparison of modeling and monitoring validates that the $30 \%-50 \%$ savings mark was being met (Hales 2014). 
In a study by Webber Energy Group (Rhodes et al. 2014), researchers examined modeling accuracy of BEopt $2.0 \mathrm{E}+$ by comparing calibrated models to utility bill data from 54 homes in Austin, Texas (hot-humid climate). This study revealed that the model has trouble predicting the energy use of homes with exceptionally low or high consumption-particularly those that use less than $5 \mathrm{kWh} / \mathrm{ft}^{2} /$ year of average energy use or more than $10 \mathrm{kWh} / \mathrm{ft}^{2} /$ year. DOE's BA research team Consortium for Advanced Residential Buildings' (CARB) current research further analyzed this finding by examining modeling accuracy at a high-detail level of three ZERHs that consume less than $5 \mathrm{kWh} / \mathrm{ft}^{2} /$ year.

\subsection{Research Questions}

CARB used utility bills and actual monitored energy use data to evaluate the performance of three ZERH projects in the Northeast versus estimates from various energy models. This study sought to answer the following research questions:

- How does actual energy use for cold climate homes built to DOE's ZERH requirements compare to predicted energy use?

- Are the findings consistent among all the research homes? Can any differences be explained?

- Should changes be made to modeling assumptions based on these research findings?

\subsection{Test Homes}

CARB evaluated performance of three homes that earned DOE ZERH certification (formerly Challenge Home certification) in Danbury, Connecticut; Old Greenwich, Connecticut; and Ithaca, New York. These homes had varying occupancy levels, fuel types, and sizes; this sample set includes all-electric and natural gas-heated homes. The following sections include details about the building specifications of each home.

\subsubsection{Danbury, Connecticut (Site 1)}

Site 1, located in Danbury, Connecticut (IECC climate zone 5A), is a 1,650- $\mathrm{ft}^{2}$, 3-bedroom, 2-1/2bath, 2-story custom home. The home stands on the site of a previous 1950s cottage; sections of the original foundation were used to build this home. In addition to DOE ZERH certification (Figure 1), it achieved Passive House Institute U.S. certification. The builder (BPC Green Builders) was recognized with a Custom Builder Award as part of DOE's 2014 Housing Innovation Awards and won for the lowest HERS Index without renewable technologies in the 2013 Connecticut Zero Energy Challenge ("Trolle Home - Danbury, CT" undated). The building component specifications are outlined in Table 3. 
Table 3. Danbury, Connecticut, Building Specifications

\begin{tabular}{|c|c|}
\hline $\begin{array}{c}\text { Building } \\
\text { Specification* }\end{array}$ & Danbury, Connecticut \\
\hline $\begin{array}{l}\text { Above-Grade } \\
\text { Walls }\end{array}$ & $\begin{array}{l}2 \times 6 \text { wall construction with } 5-1 / 2 \text { in. of blown cellulose }(\mathrm{R}-20) \\
\text { plus two layers of } 5-1 / 2-\text {-in. polyisocyanurate foam board }(\mathrm{R}-37)\end{array}$ \\
\hline $\begin{array}{l}\text { Foundation/Slab, } \\
\text { Floor }\end{array}$ & $\begin{array}{l}\text { 12-in. expanded polystyrene foam board (R-58) under new frost-protected } \\
\text { shallow slab foundation, and 6-in. expanded polystyrene (R-29) applied to } \\
\text { exterior of the shallow slab walls. } 2 \text { in. of } 2 \text {-lb spray polyurethane foam plus } \\
5-1 / 2 \text { in. of } 1 / 2 \text {-in. spray polyurethane foam (R-34) insulates the } 2 \times 8 \text { floor } \\
\text { joists over the existing unconditioned basement with } 2-1 / 2 \text { in. of mineral } \\
\text { wool boards (R-10) under the joists. }\end{array}$ \\
\hline Windows & $\begin{array}{c}\text { Polyvinyl chloride frames and triple glazing with argon gas fill and two } \\
\text { low-e coatings with U-value of } 0.12 \text {. Skylights are clad wood with U-value } \\
\text { of } 0.14 \text {. }\end{array}$ \\
\hline Roof/Ceiling & Blown cellulose fills the 18-in. open-web roof trusses (R-68). \\
\hline Infiltration & $0.46 \mathrm{ACH} 50$ \\
\hline Lighting & A mixture of fluorescent and light-emitting diode fixtures \\
\hline Ventilation & $\begin{array}{l}\text { Ventilation provided by an energy recovery ventilator (ERV) that exhausts } \\
\text { from the bathrooms and kitchen and provides fresh air to the entire house. }\end{array}$ \\
\hline $\begin{array}{l}\text { HVAC and } \\
\text { Water Heating }\end{array}$ & $\begin{array}{l}\text { One-ton air-source heat pump. Ducted fan moves conditioned air around the } \\
\text { house. High-efficiency condensing tankless propane-fired water heater. }\end{array}$ \\
\hline Appliances & ENERGY STAR ${ }^{\circledR}$ appliances, condensing dryer \\
\hline Renewables & Solar ready but not yet installed \\
\hline
\end{tabular}

* DOE (2014c)
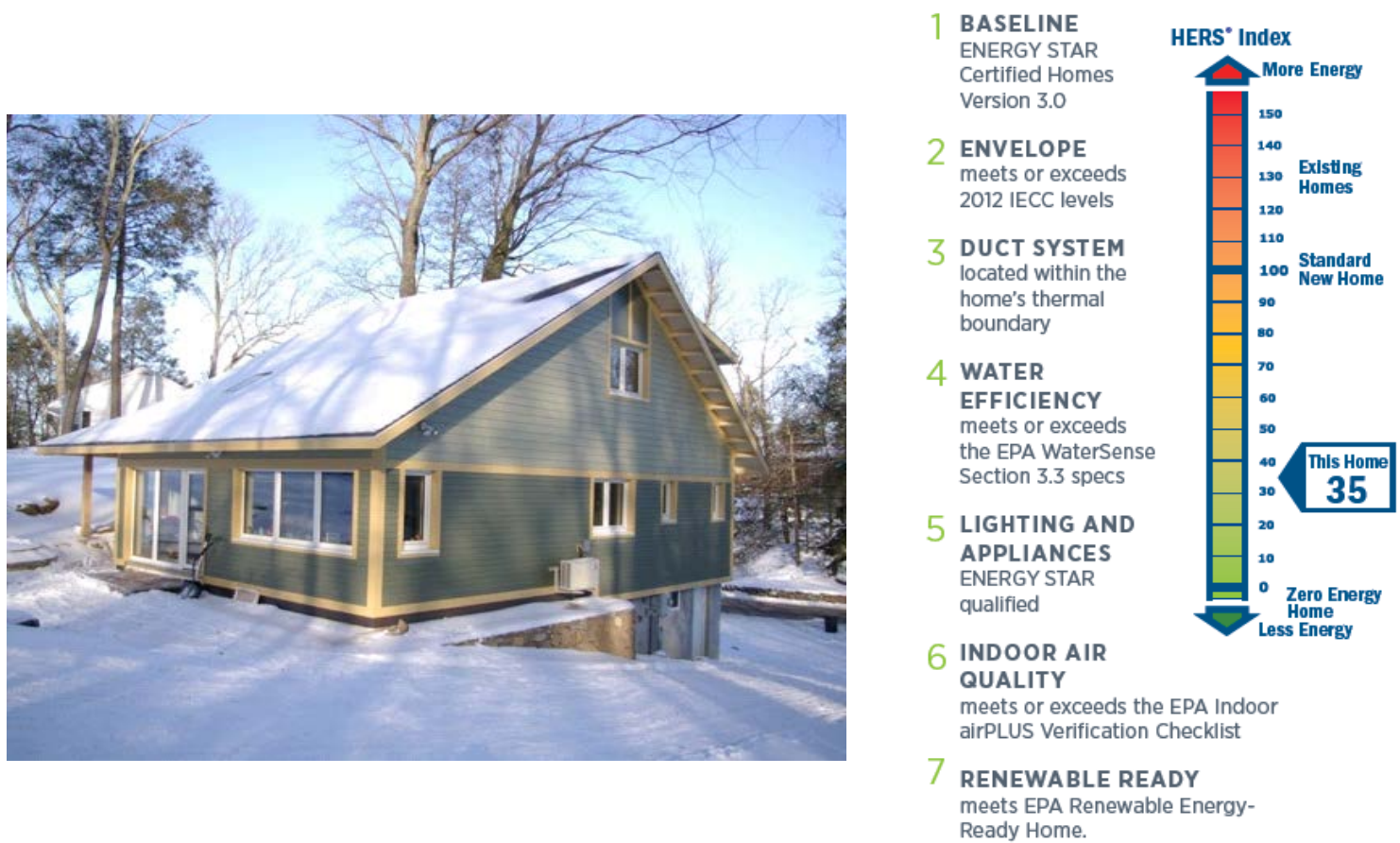

Figure 1. (Left) Photo of Danbury, Connecticut, home; (Right) ZERH HERS index certificate 


\subsubsection{Old Greenwich, Connecticut (Site 2)}

Site 2, located in Old Greenwich, Connecticut (IECC climate zone 5A), is a 2,700- $\mathrm{ft}^{2}, 4-$ bedroom, 3-1/2-bath, 2-story traditional neocolonial home. In addition to receiving DOE ZERH certification, the builder (Preferred Builders, Inc.) was the grand winner for custom homes as part of DOE's 2013 Housing Innovation Awards and took second place in the 2012 Connecticut Zero Energy Challenge. Figure 2 shows a photo of this home and its ZERH HERS index certificate; Table 4 outlines its building component specifications.
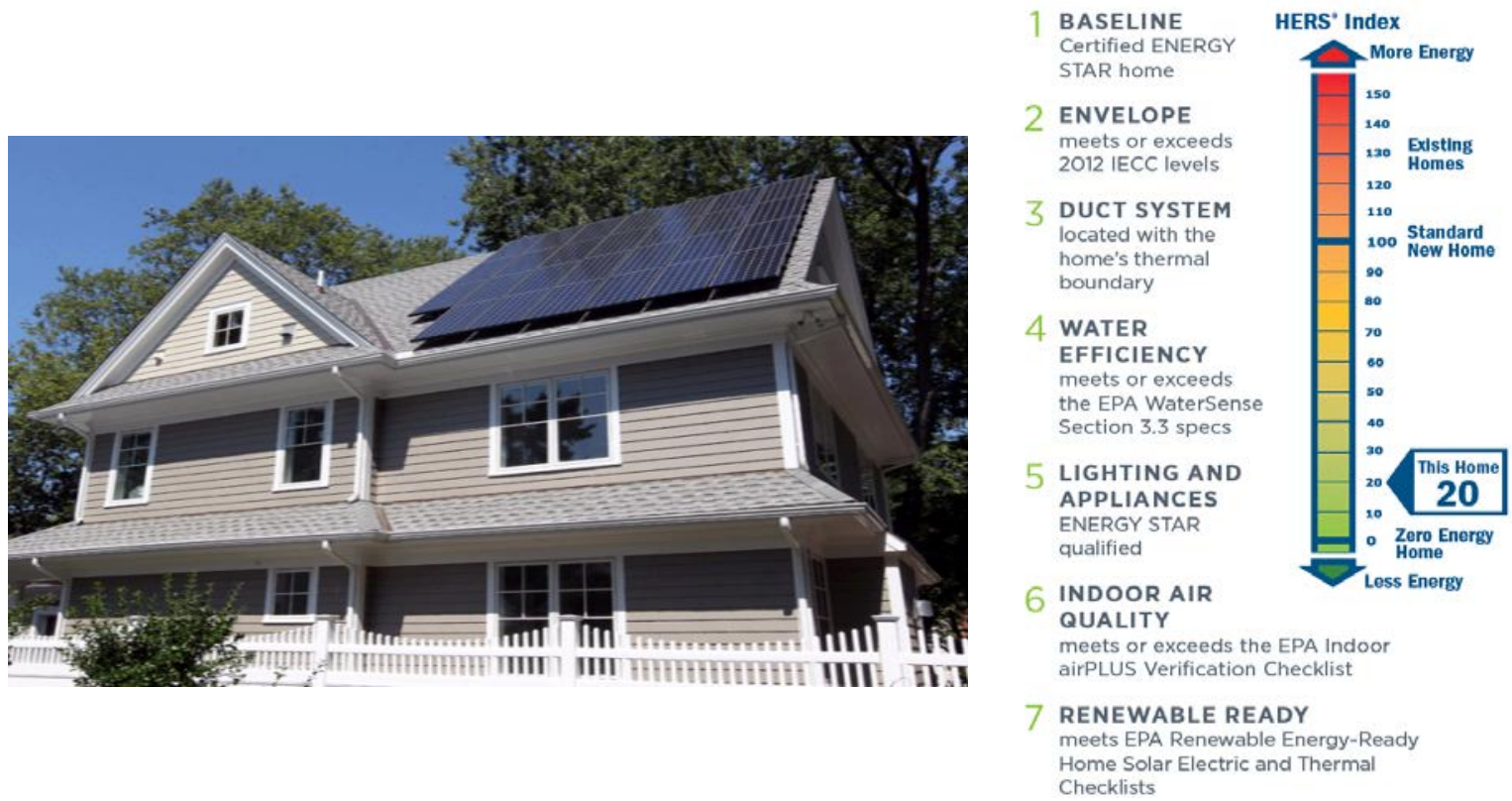

Figure 2. (Left) Photo of Old Greenwich, Connecticut, home; (Right) ZERH HERS index certificate Table 4. Old Greenwich, Connecticut, Building Specifications

\begin{tabular}{|c|c|}
\hline Building Specification* & Old Greenwich, Connecticut \\
\hline Above-Grade Walls & $\begin{array}{c}1-1 / 2 \text {-in. extruded polystyrene (R-7.5) over sheathing and R-21 blown cavity } \\
\text { insulation }\end{array}$ \\
\hline Foundation/Slab, Floor & $\begin{array}{l}\text { 3-in. closed-cell spray polyurethane foam on interior foundation wall (R-20) } \\
\text { and under the slab (R-13) }\end{array}$ \\
\hline Windows & $\begin{array}{l}\text { Dual pane, low-e windows w/vinyl frame (U-0.28/solar heat gain coefficient- } \\
\qquad 0.27)\end{array}$ \\
\hline Roof/Ceiling & $\begin{array}{l}\text { Unvented attic with 5-1/2-in. closed-cell spray polyurethane foam (R-36), 3-1/2- } \\
\text { in. foil-faced fiberglass (R-13), and cool roof (solar reflectance index }=29 \text { ) }\end{array}$ \\
\hline Infiltration & $1.0 \mathrm{ACH}_{50}$ \\
\hline Lighting & $100 \%$ light-emitting diode fixtures \\
\hline Ventilation & ERV with carbon dioxide override control, all exhaust fans vented to outside \\
\hline $\begin{array}{l}\text { HVAC and Water } \\
\text { Heating }\end{array}$ & $\begin{array}{l}\text { Two 1-1/2-ton seasonal energy-efficiency ratio } 16 \text { single-stage air conditioners, } \\
\text { two hydro-coils ( } 24 \mathrm{kBtu} / \mathrm{h} \text { heating capacity) with variable-speed fans, natural } \\
\text { gas wall-mounted combi-boiler, } 96 \% \text { annual fuel utilization efficiency, ducts } \\
\text { (R-8 fiber board) and air handling units located within thermal/air barrier. } \\
\text { Less than } 2 \mathrm{cfm} / 100 \mathrm{ft}^{2} \text { total leakage. }\end{array}$ \\
\hline Appliances & ENERGY STAR appliances \\
\hline Renewables & 7.44-kW photovoltaic (PV) system \\
\hline
\end{tabular}




\subsubsection{Ithaca, New York (Site 3)}

Site 3 is located in Ithaca, New York (IECC climate zone 6A) and is a 1,664- $\mathrm{ft}^{2}, 3$-bedroom, 2bath, 2 -story Passive House. It is part of a community-scale development known as Ecovillage that seeks to provide housing that is affordable, durable, sustainable, comfortable, and accessible. In addition to receiving DOE ZERH certification, the builder (AquaZephyr, LLC) was recognized with a Production Builder Award during the 2014 DOE Housing Innovation Awards. Figure 3 shows a photo of this home; Table 5 outlines the building component specifications.
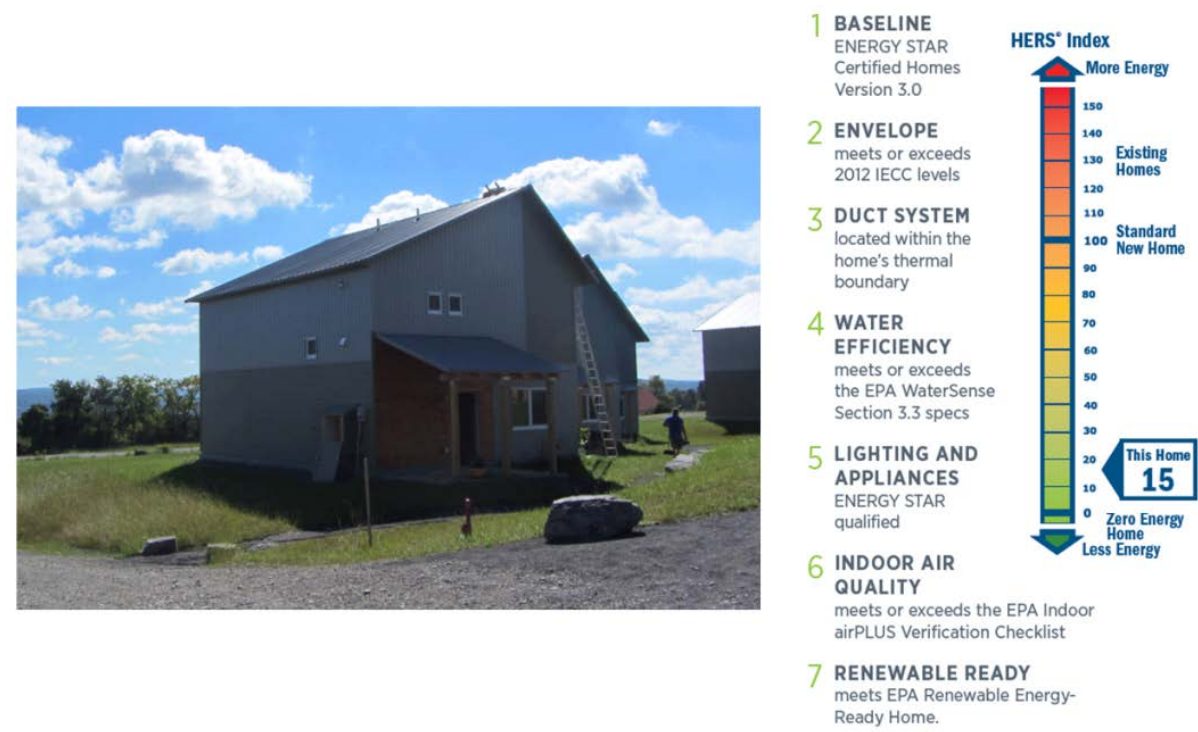

Figure 3. (Left) Photo of Ithaca, New York, home; (Right) ZERH HERS index certificate

Table 5. Ithaca, New York, Building Specifications

\begin{tabular}{|c|c|}
\hline Building Specification* & Ithaca, New York \\
\hline Above-Grade Walls & $\begin{array}{l}\text { Double } 2 \times 4 \text { stud wall with } 5 \text {-in. gap ( } 12 \text {-in. depth); R-22 (3-1/2 in. at R- } \\
6.3 / \text { in.) closed cell spray foam and R-30 cellulose }(8-1 / 2 \text { in. at R-3.5/in.) }\end{array}$ \\
\hline Foundation/Slab & $\begin{array}{l}\mathrm{R}-19.5 \text { rigid at perimeter to } 4 \mathrm{ft} \text { below slab on grade; R-36 at } 2 \mathrm{ft} \text { under } \\
\text { slab }\end{array}$ \\
\hline Windows & Triple-pane, low-e windows with U-0.17 and SHGC-0.62 \\
\hline Roof/Ceiling & Metal roof, R-90 cellulose ( 25 in. at R-3.6/in.) \\
\hline Infiltration & $0.42 \mathrm{ACH} 50$ \\
\hline Lighting & $\begin{array}{c}72 \% \text { light-emitting diodes, } 28 \% \text { compact fluorescent lamps; ENERGY } \\
\text { STAR ceiling fans }\end{array}$ \\
\hline Ventilation & ERV with dedicated duct system that meets ASHRAE 62.2 rates \\
\hline $\begin{array}{l}\text { HVAC and Domestic Hot } \\
\text { Water (DHW) }\end{array}$ & $\begin{array}{c}\text { Electric baseboard, solar thermal preheat with electric storage tank, } 0.84 \\
\text { energy factor }\end{array}$ \\
\hline Appliances & ENERGY STAR refrigerator and dishwasher \\
\hline Renewables & $4.4 \mathrm{~kW}$ PV and DHW system \\
\hline
\end{tabular}




\section{Methodology}

CARB examined energy consumption at three ZERH homes across the Northeast to validate ZERH savings claims. This process included monitoring end-use consumption, creating a series of energy models, and analyzing homeowner's utility bills (when available). The methodology used for each process is explained in the following sections. All data are presented in terms of site energy consumption because this energy metric is used to calculate the HERS Index used in the ZERH certification process.

For this study, a valid savings claim was one in which the actual measured site energy consumption was within $5 \%$ or lower of the model estimates. The main concern was whether estimated energy savings that exceed those of the 2006 IECC reference model were grossly overestimated (thus $5 \%$ or lower threshold rather than $0 \%$ or lower). Although underestimating is also not ideal, being conservative with savings claims is not a significant concern because it does not diminish the value of the program.

\subsection{Determining Actual Energy Use}

The first step of the analysis was to gather information on the actual energy consumption over the course of 1 year. Shortly after each home was initially occupied CARB installed a SiteSage Energy Management System (formerly eMonitor) to measure and log electricity consumption of various end-use loads in the home (with an accuracy of $\pm 2 \%$ of the reading). The SiteSage system is a circuit-level home energy monitoring system created by Powerhouse Dynamics. Figure 4 shows an example SiteSage dashboard from circuit-level monitoring at Site 1.

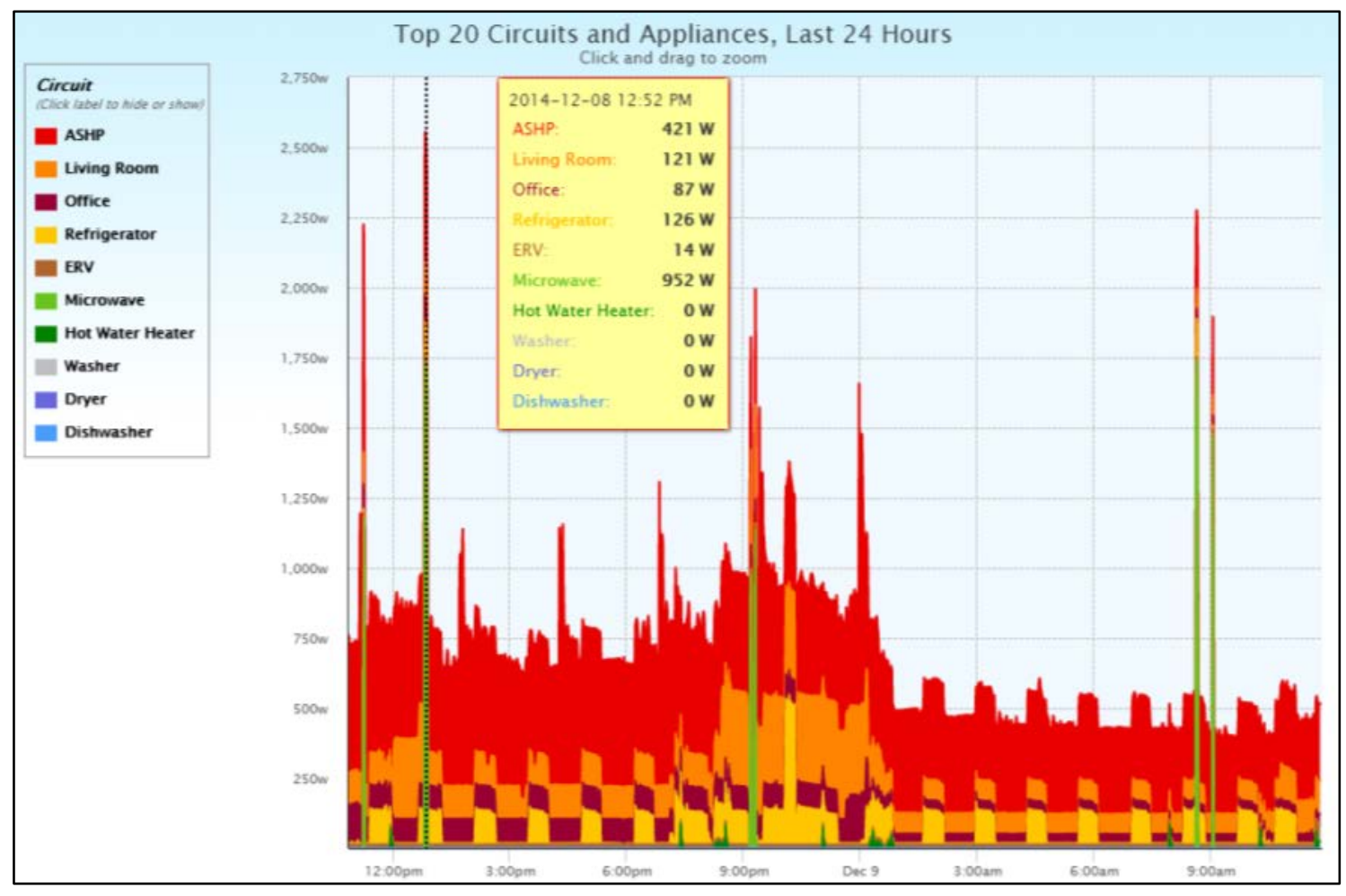

Figure 4. Circuit monitoring at Danbury, Connecticut, home 
To allow for a consistent comparison with end-use categories that are available for output in the energy model software, CARB installed current transformers at the panel so that loads could be grouped into the following categories:

- Heating

- Cooling

- Lights, Appliances, and Miscellaneous Electricity Loads (LAMELs) and Domestic Hot Water Use ${ }^{1}$

- Ventilation

- PV Generation.

Two monitoring methods were used to collect and monitor data about indoor air conditions at each site. At Site 3, indoor temperature and relative humidity (RH) measurements were incorporated into the SiteSage monitoring platform through the PowerWise inDAC sensor package. This task involved running temperature sensor wires through the home during construction and mounting sensors in each room. This system provided a live-update temperature/RH measurement of each room in the house. The second method, which was used at Sites 1 and 2, consisted of placing temperature/RH data loggers in various rooms and making onsite downloads at regular increments (approximately every 4 months). These indoor temperature/RH data were used to estimate set point temperatures to be used in the energy modeling.

Natural gas was the primary heating fuel for Site 2. CARB used utility bill data supplied by the homeowner to determine gas therms used each month. When electricity utility bills were available, they were validated against - and used in conjunction with - SiteSage electricity measurements to perform a utility bill disaggregation method. This analysis involved developing estimates of annual heating and cooling energy use based on total monthly electricity and gas consumption data and outdoor temperature condition data. The base load was defined by the swing season energy consumption. Estimates of non-space-conditioning loads were also formed by examining energy use during mild swing seasons, usually during April and October when space-conditioning loads are minimal or zero.

\subsection{Modeling}

The second aspect of this study involved generating a series of energy models for each home. CARB used two modeling software programs: Noresco's REM/Rate v14.5 and BEopt 2.3 E+. For REM/Rate models, end-use loads could be viewed as an annual sum only. For BEopt models, an application for visual analysis of time-series data called DVIEW was used to organize energy model outputs into monthly increments.

\footnotetext{
${ }^{1}$ Site 1 uses propane for hot water and Site 2 uses natural gas. Site 3 uses an electric resistance tank that is supplemented by a solar hot water loop.
} 
CARB used these two software programs to create four separate models for each home in this study:

- A REM/Rate base model that was used to generate a HERS score

- A baseline BEopt model that uses defaults per the BA House Simulation Protocols (Wilson et al. 2014)

- A tuned BEopt model with corrections for actual weather, occupants, and temperature set points

- A benchmark model to determine energy use in the same size home if it had been built to IECC 2006 code minimums.

Once the base BEopt model was created, CARB modified several model inputs to create a tuned model that better reflected conditions during the monitoring period. The number of occupants in a home has a significant impact on energy consumption, specifically on LAMELs. Thus, characterizing occupancy correctly in a model will significantly impact the accuracy of its results - especially for low-load homes. BEopt estimates the home's occupancy based on the number of bedrooms input into the model. For single-family homes, it uses the following relationship between number of bedrooms and number of occupants:

$$
\text { Number of occupants }=0.59 \times \mathrm{N}_{\mathrm{br}}+0.87
$$

For the range of bedrooms that are selectable in a BEopt model, Table 6 relates the number of bedrooms modeled to the typical number of occupants in the home.

Table 6. Relationship Between Number of Bedrooms and Number of Occupants

\begin{tabular}{c|c}
\hline \# of Bedrooms & Occupants \\
\hline $\mathbf{1}$ & 1.46 \\
$\mathbf{2}$ & 2.05 \\
$\mathbf{3}$ & 2.64 \\
$\mathbf{4}$ & 3.23 \\
$\mathbf{5}$ & 3.82 \\
\hline
\end{tabular}

Because CARB knew the exact number of occupants who lived in each test home during the monitoring period, the energy models were adjusted so that the number of bedrooms that were modeled more accurately represented the true number of occupants (Table 7).

Table 7. Number of Bedrooms Modeled

\begin{tabular}{c|c|c|c}
\hline Location & $\begin{array}{c}\text { Actual Number of } \\
\text { Occupants in the } \\
\text { Home }\end{array}$ & $\begin{array}{c}\text { Number of } \\
\text { Bedrooms in the } \\
\text { Home }\end{array}$ & $\begin{array}{c}\text { Number of } \\
\text { Bedrooms } \\
\text { Modeled }\end{array}$ \\
\hline Site 1 & 3 & 3 & 3 \\
\hline Site 2 & 3 & 4 & 4 \\
Site 3 & 1 & 3 & 1 \\
\hline
\end{tabular}


Models were also adjusted based on indoor and outdoor air temperatures. As described in Section 2.1, indoor temperatures were measured in several locations across each home. The intent was to accurately develop an average indoor air temperature that could be used to estimate heating and cooling set points. The BA House Simulation Protocols assume default set points of $71^{\circ} \mathrm{F}$ for heating and $76^{\circ} \mathrm{F}$ for cooling. CARB adjusted the set point in the model (see Table 8) based on the average indoor temperatures during heating and cooling periods, which were relatively fixed set points.

Table 8. Average Indoor Temperatures During Monitoring Period

\begin{tabular}{c|c|c}
\hline Location & $\begin{array}{c}\text { Average Heating } \\
\text { Indoor Temperature } \\
\left({ }^{\circ} \mathbf{F}\right)\end{array}$ & $\begin{array}{c}\text { Average Cooling } \\
\text { Indoor Temperature } \\
\left({ }^{\circ} \mathbf{F}\right)\end{array}$ \\
\hline Site 1 & 68 & 74 \\
Site 2 & 68 & 71 \\
Site 3 & 67 & N/A \\
\hline
\end{tabular}

BEopt models generally use a TMY3 weather file to predict a building's energy consumption under typical weather conditions. Because the TMY data are normalized, they are not representative of true climatic conditions during the data collection period. When monitored data are compared to energy models, the prediction needs to be adjusted based on actual weather conditions from the monitoring period. CARB gathered historical weather data from the closest weather stations to each site. Average monthly outdoor dry bulb $\left({ }^{\circ} \mathrm{F}\right)$ and dew point $\left({ }^{\circ} \mathrm{F}\right)$ temperatures were calculated for each month of the monitoring period. CARB used Elements (a weather file editor and visualizer) to scale TMY3 weather files so that they had the same monthly temperature averages as those during the actual monitoring period. This was done rather than inputting the actual temperature data to keep the diurnal temperature, solar, and wind relationships in the TMY3 weather files. To demonstrate differences in weather conditions, HDD65 and cooling degree days (base $74^{\circ} \mathrm{F}$ ) were calculated for each weather data set. Table 9 shows the difference between real-time and TMY3 weather for 2014.

Table 9. Difference in Weather Data Between Monitoring Period and TMY3 Data

\begin{tabular}{c|c|c|c|c|c|c}
\hline \multirow{2}{*}{ Location } & \multicolumn{2}{|c|}{ Monitoring Period } & Scaled Degree Days & \multicolumn{2}{c}{ TMY3 } \\
\cline { 2 - 7 } & Start & End & HDD65 & CDD74 & HDD65 & CDD74 \\
\hline Site 1 & $1 / 1 / 2014$ & $12 / 31 / 2014$ & 6,766 & 169 & 6,223 & 189 \\
Site 2 & $1 / 1 / 2013$ & $1 / 1 / 2014$ & 5,764 & 196 & 5,571 & 159 \\
Site 3 & $12 / 1 / 2013$ & $12 / 1 / 2014$ & 7,475 & 124 & 6721 & 186 \\
\hline
\end{tabular}

Adjusting the weather file to account for conditions such as wind speed, solar irradiance, and atmospheric pressure would have further increased the accuracy of the energy model; however, these were determined to have a less significant impact than temperature and are more difficult to obtain from public resources. 


\section{Results}

\subsection{Annual Comparison of Monitored Versus Modeled Use}

The energy consumption estimates were compared against the data collected to validate the various models (Table 10). Total consumption was analyzed as site energy use to compare energy consumption (natural gas and electricity). In these cases, actual use never significantly exceeds the models' predictions. Thus, the same inference remains - these homes achieve approximately equal or better performance than the models have predicted.

Table 10. Summary of Modeled Versus Actual Energy Consumption (Excluding PV)

\begin{tabular}{c|c|c|c}
\hline $\begin{array}{c}\text { Site Energy } \\
\text { (MBtu/year) }\end{array}$ & Site 1 & Site 2 & Site 3 \\
\hline Estimated REM/Rate Savings & $65 \%$ & $58 \%$ & $44 \%$ \\
\hline Actual Measured Data & 33.4 & 88.6 & 16.4 \\
REM/Rate Model Estimates & 31.5 & 84.8 & 27.8 \\
\hline REM/Rate \% Difference & $6.0 \%$ & $4.5 \%$ & $-41.0 \%$ \\
Base BEopt Model Estimates & 32.4 & 91.3 & 29.4 \\
\hline Base BEopt \% Difference & $3.1 \%$ & $-3.0 \%$ & $-44.2 \%$ \\
Tuned BEopt Model Estimates & 32.7 & 87 & 24.1 \\
\hline Tuned BEopt \% Difference & $2.1 \%$ & $1.8 \%$ & $-32.0 \%$ \\
\hline Adjusted REM/Rate Savings & $61 \%$ & $55 \%$ & $62 \%$ \\
\hline
\end{tabular}

The research team investigated energy end-use consumption to determine discrepancies and alignments. Table 11 shows a summary of the percentage difference between measured and modeled electricity site energy consumption. Site 3 did not have cooling so no value is reported. Because DHW use was not separately metered at each site, it is grouped with LAMELs for this analysis. For these projects, the models have significant discrepancies in each end-use category. These discrepancies highlight the need for further research into modeling energy performance in high-efficiency homes.

Table 11. Electricity Site Energy Consumption Comparison Summary: Percent Difference Between Measured and Modeled

\begin{tabular}{|c|c|c|c|c|c|c|c|c|c|}
\hline & \multicolumn{3}{|c|}{ Site 1} & \multicolumn{3}{|c|}{ Site 2} & \multicolumn{3}{|c|}{ Site 3} \\
\hline Model & $\begin{array}{l}\text { REM/ } \\
\text { Rate }\end{array}$ & $\begin{array}{c}\text { Base } \\
\text { BEopt }\end{array}$ & $\begin{array}{l}\text { Tuned } \\
\text { BEopt }\end{array}$ & $\begin{array}{l}\text { REM/ } \\
\text { Rate }\end{array}$ & $\begin{array}{c}\text { Base } \\
\text { BEopt }\end{array}$ & $\begin{array}{l}\text { Tuned } \\
\text { BEopt }\end{array}$ & $\begin{array}{l}\text { REM/ } \\
\text { Rate }\end{array}$ & $\begin{array}{l}\text { Base } \\
\text { BEopt }\end{array}$ & $\begin{array}{l}\text { Tuned } \\
\text { BEopt }\end{array}$ \\
\hline Heating $^{a}$ & $98 \%$ & $96 \%$ & $109 \%$ & $74 \%$ & $262 \%$ & $290 \%$ & $-29 \%$ & $66 \%$ & $41 \%$ \\
\hline Cooling & $-29 \%$ & $85 \%$ & $57 \%$ & $150 \%$ & $178 \%$ & $61 \%$ & - & - & - \\
\hline $\begin{array}{c}\text { LAMELS and } \\
\text { DHW }^{\mathrm{b}}\end{array}$ & $2 \%$ & $-13 \%$ & $-13 \%$ & $-34 \%$ & $-32 \%$ & $-32 \%$ & $-45 \%$ & $-57 \%$ & $-45 \%$ \\
\hline Total & $10 \%$ & $4 \%$ & $4 \%$ & $-13 \%$ & $-9 \%$ & $-15 \%$ & $-41 \%$ & $-44 \%$ & $-32 \%$ \\
\hline
\end{tabular}

\footnotetext{
${ }^{\mathrm{a}}$ For Site 2 the heating fuel is natural gas so only fan/pump energy is accounted for in this analysis.

${ }^{\mathrm{b}}$ Sites 1 and 2 are showing only LAMELS because Site 1 uses propane for DHW and Site 2 uses natural gas.
} 


\subsection{Monthly Comparison of Monitored Versus Modeled Use}

CARB performed monthly data analysis to dig deeper into potential causes for modeling discrepancies. For this analysis, only results from BEopt were available because REM does not break energy consumption down by month. Results from the tuned BEopt model were compared to total monitored monthly electricity consumption. Results from each site showed different results but the trend was the same - the models typically overpredicted total consumption. Figure 5 through Figure 7 show a comparison of measured and monitored electricity consumption for each site.

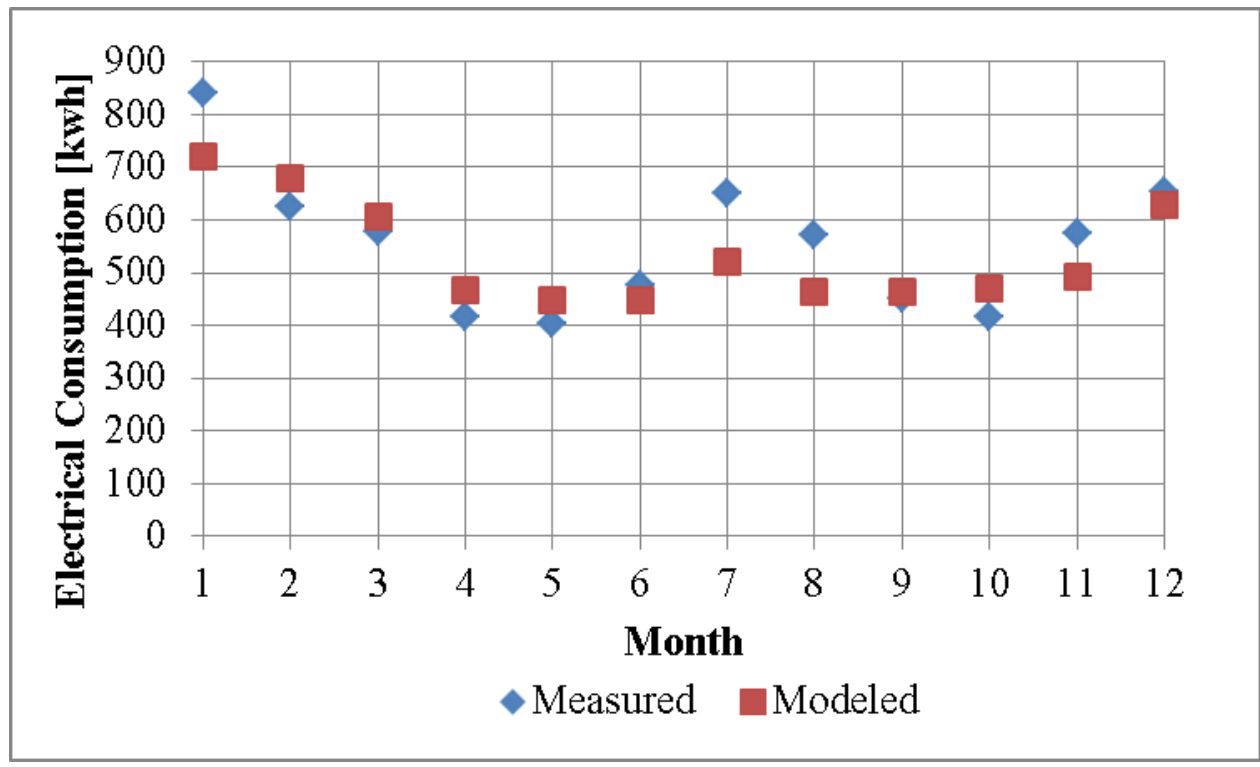

Figure 5. Site 1: Total monthly electricity use-measured versus modeled

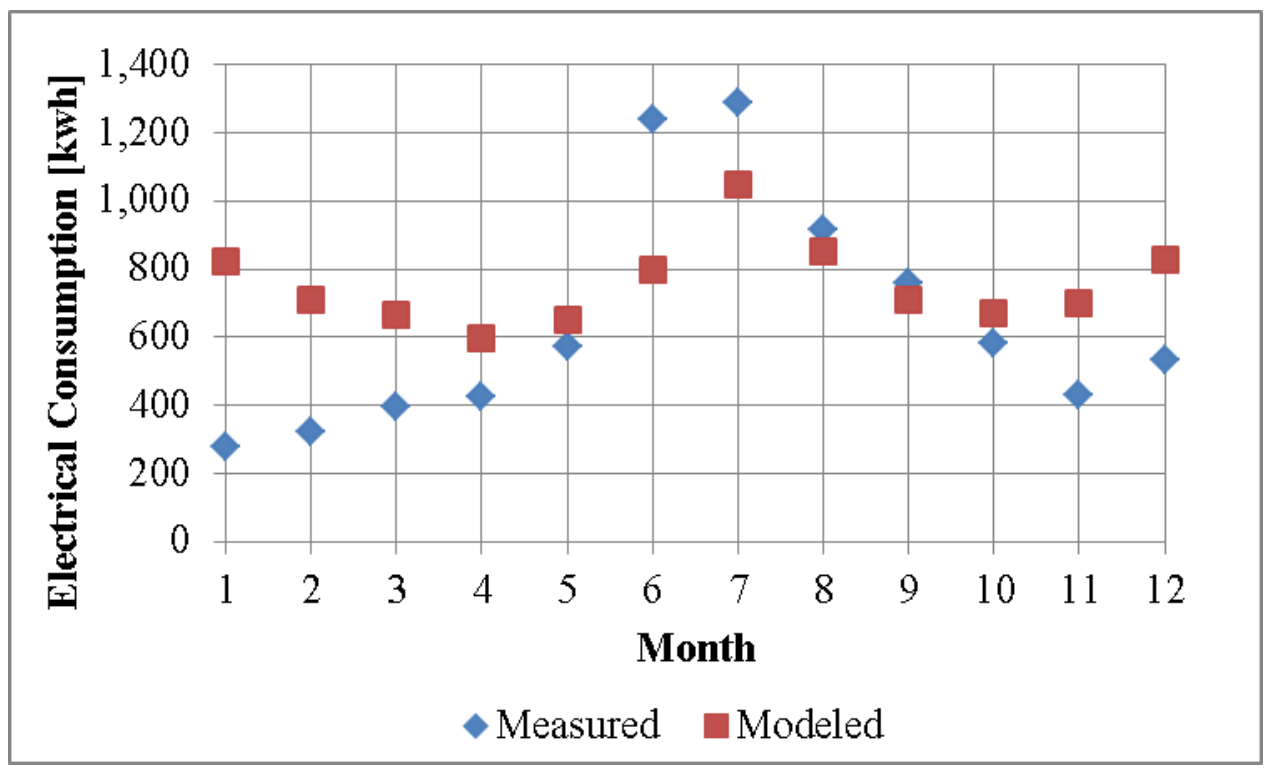

Figure 6. Site 2: Total monthly electricity use-measured versus modeled 


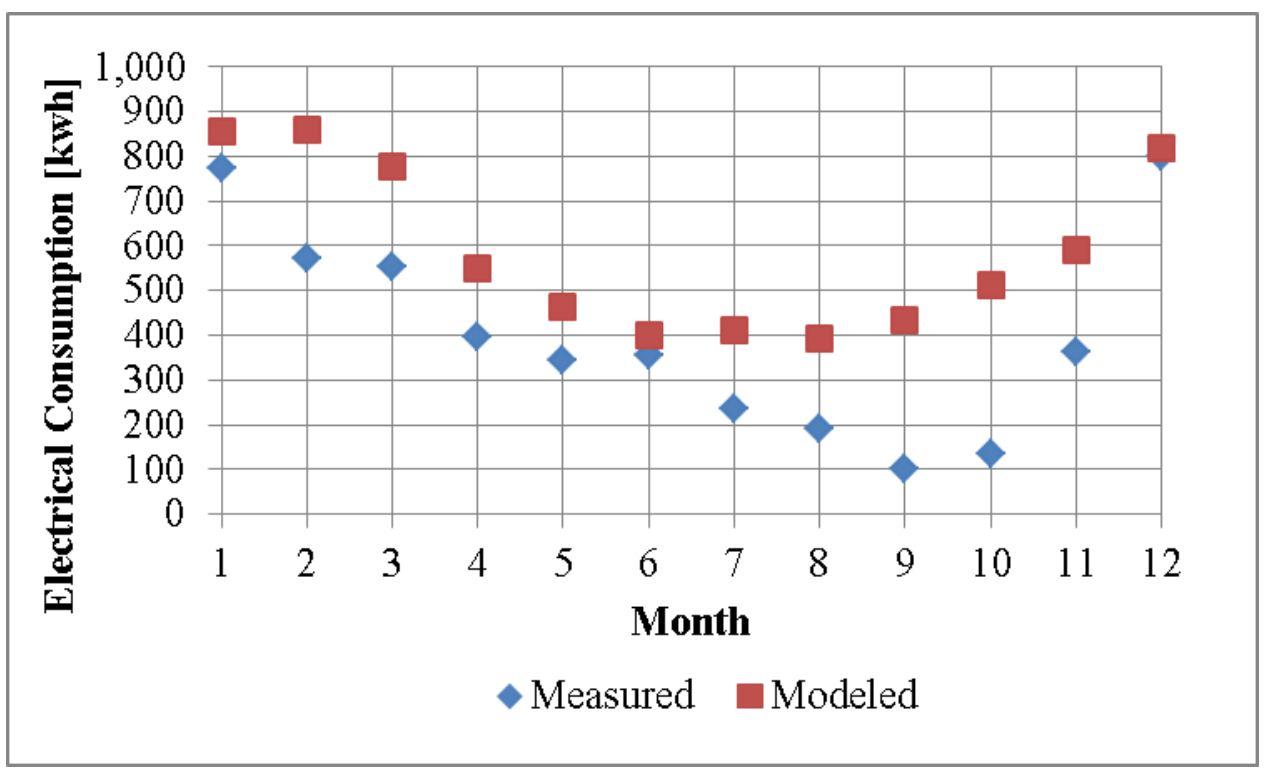

Figure 7. Site 3: Total monthly electricity use-measured versus modeled

Analysis of circuit-level end uses revealed that total consumption analysis did not properly convey the accuracy of the model. For instance, Site 1 showed very good overall agreement between total energy used and total electrical energy predicted by BEopt. More detailed analysis by end use shows that the model consistently underpredicted the mini-split heat pump's electricity consumption for space conditioning and typically overpredicted LAMEL consumption. These discrepancies offset each other to create predicted total energy consumption that was very close to measured consumption. In all three cases, during many months the model was within $\pm 5 \%$ of actual use, but during other months the values were underpredicted by a factor of 4 .

\subsubsection{Site 1}

Figure 8 shows a monthly comparison of end-use consumption at Site 1. Even with the modeled number of bedrooms at three (representing use that would be characteristic of an average occupancy of 2.64 persons per day), Site 1 significantly overpredicted LAMELs during most months. The home's primary heating and cooling source was a 1-ton mini-split heat pump (Mitsubishi FE12NA). CARB adjusted BEopt's modeling inputs to match manufacturer-rated specifications. Heating and cooling energy delivered by the mini-split heat pump was underestimated for every month. The most extreme underestimate occurred in the coldest months (December and January). Ventilation was a minimal load and model accuracy varied from month to month. The greatest discrepancy occurred during cold months when the installed ERV regularly kicked into electric resistance defrost mode (which cannot be accounted for in the energy model software) to prevent the heat transfer medium from freezing.

After final modeling and utility bill analysis was completed, the homeowner at Site 1 revealed that a standalone dehumidifier was run during July and August because he felt that the mini-split was not adequately controlling humidity. Further analysis of the data pinpointed a spike in total energy consumption between July 14 and August 10. To examine the impact that an additional 
dehumidifier would have on modeled predictions, CARB created a series of humidity test models. If the dehumidifier was set to $60 \% \mathrm{RH}$, no increase occurred. If set to $50 \% \mathrm{RH}$, cooling energy consumption was predicted to increase by $97 \mathrm{kWh}$. Rather than repeating the entire analysis for this small additional load, CARB left the temporary standalone dehumidifier out of the model. The additional load was not enough to affect research conclusions; however, the JulyAugust LAMELs spike likely resulted from this load.

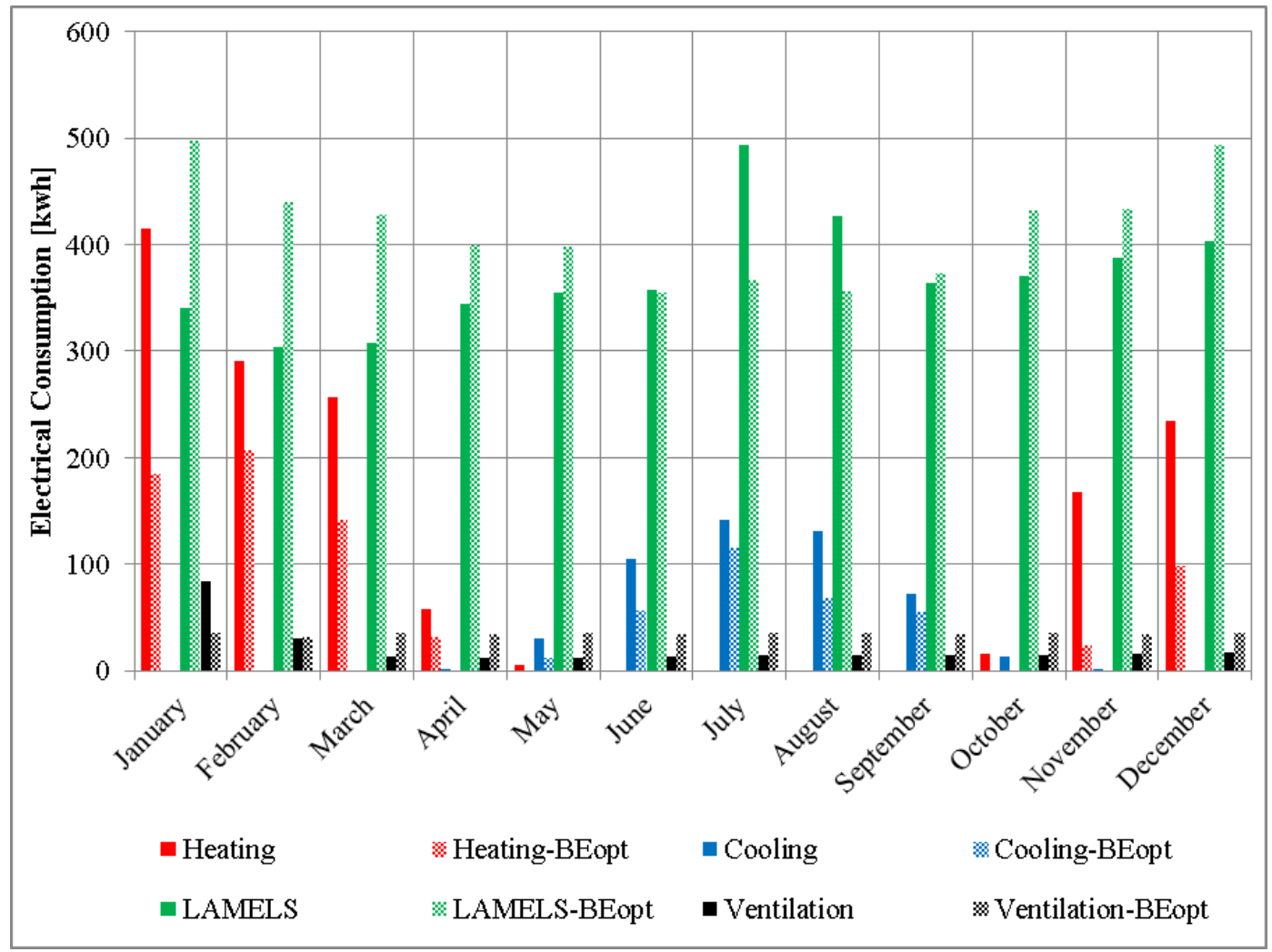

Figure 8. Site 1: Monthly electricity end use-measured versus modeled

\subsubsection{Site 2}

Figure 9 shows a comparison of end uses that were predicted in the tuned model and measured throughout the monitoring year at Site 2. Most notably, the model significantly overpredicted LAMELs for most months. In January, the overprediction was by a factor of 8. Unlike other sites in this study, this home is heated by natural gas; thus, heating-related electricity loads are minimal. For periods with cooling, actual cooling consumption consistently exceeded the model predictions - often by at least a factor of 2 - even with updated modeling inputs for the manufacturer's specified seasonal energy-efficiency ratio and capacity. From January through July, actual ventilation loads were higher than predicted; however, from August through December actual loads were lower than predicted. With this decrease in ERV consumption, CARB suspected that the homeowner changed the ventilation strategy midway through the monitoring period. During further investigation, CARB determined that the add-on carbon dioxide demand control for the ventilation system was frequently pushing the ventilation rate to maximum flow because the setting was low-600 ppm. This was later raised to $900 \mathrm{ppm}$, which drastically reduced the frequency of boost ventilation. 


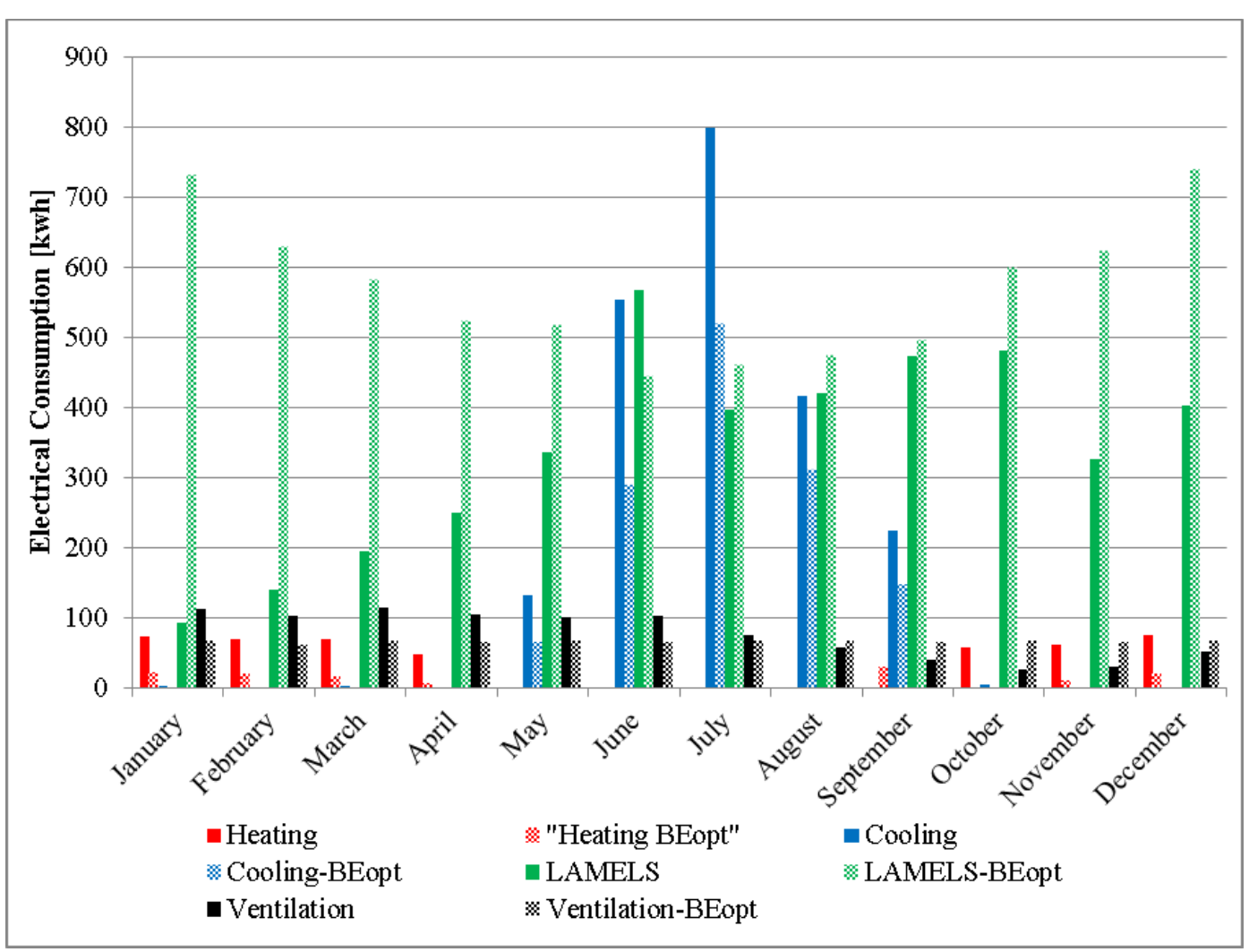

Figure 9. Site 2: Monthly electricity end use-measured versus modeled

Gas use (therms) of the tuned model was compared to utility bill data for Site 2. Utility bill data include gas used by gas appliances and heating; thus, CARB estimated nonheating gas use as the average consumption from June through August. Figure 10 shows that actual use was slightly higher than predicted for all months except November. Based on consumption data from the summer months, the model underestimated nonheating gas use by approximately 10 therms per month. Interestingly, total gas use was underestimated by an average of approximately 13 therms per month. This suggests that the discrepancy in the model's total gas use may be largely attributed to the underprediction in non-space-conditioning loads (water heating and gas cooking). 


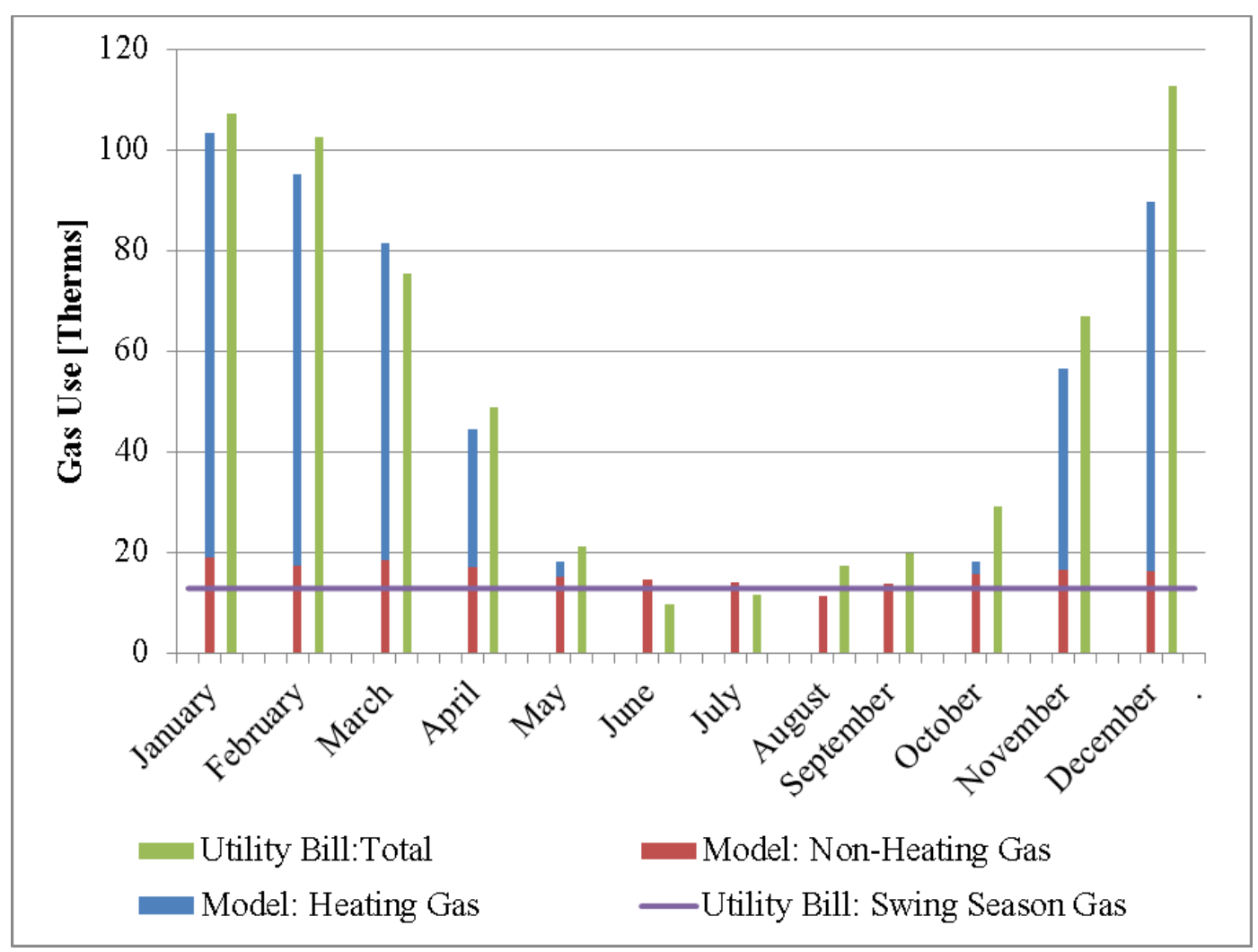

Figure 10. Site 2: Monthly gas end use-measured versus modeled

\subsubsection{Site 3}

Figure 11 compares actual monthly electricity use to modeling predictions at Site 3 . This site produced the greatest overall discrepancy between modeled and metered consumption. This site also happened to have the lowest overall energy usage of all three homes examined. As seen with other sites, one key trend is that LAMELs use is often lower than the model's prediction. One possible explanation may involve this particular home's occupancy schedule-it was occupied by one person who was not consistently home. Modeled predictions of ventilation rates are generally in line with actual use. Even with indoor set points adjusted, the model always overpredicted heating; the greatest discrepancy occurred during December and November. This is likely because this home is a Passive House and the energy model does not adequately account for solar heat gain during the winter months. During most months, DHW use was also overpredicted. The greatest discrepancies happened during the summer months when solar DHW from the evacuated tube collectors could handle most of the load. 


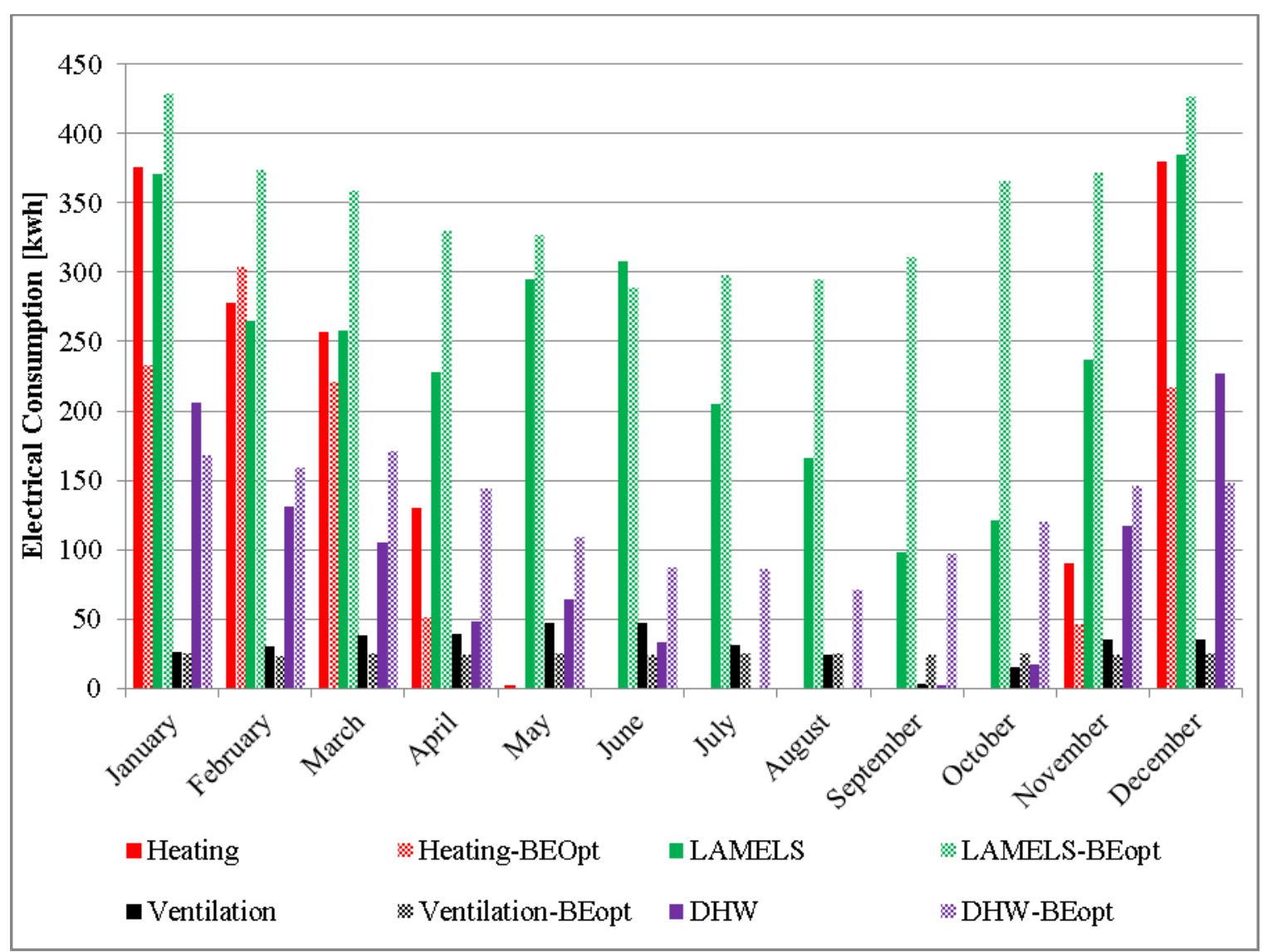

Figure 11. Site 3: Monthly electricity end use-measured versus modeled

\subsubsection{Site Generation}

For the homes that used solar PV, a large fraction of their predicted site energy savings hinged on the amount of energy that their PV array could generate. Therefore, it is useful to examine how much energy was predicted under average solar conditions (such as TMY3 data) compared to production during the monitoring period (Table 12). PV generation at Site 2 was $91 \%-95 \%$ of the predicted values and the measured PV generation at Site 3 was $94 \%-98 \%$ of the predicted values. Although both models overpredicted PV generation, these estimates were apparently quite accurate. The discrepancy between the actual and predicted results was likely caused by the heavy snowstorms that covered the PV panels with snow for part of the winter.

Table 12. PV Generation: Modeled Versus Measured

\begin{tabular}{c|c|c|c}
\hline & $\begin{array}{c}\text { REM/Rate Model } \\
(\mathbf{k W h})\end{array}$ & $\begin{array}{c}\text { BEopt Model } \\
\mathbf{( k W h )}\end{array}$ & $\begin{array}{c}\text { Actual Measured } \\
(\mathbf{k W h})\end{array}$ \\
\hline Site 2 & 8,383 & 8,705 & 7,926 \\
Site 3 & 5,361 & 5,137 & 5,036 \\
\hline
\end{tabular}




\subsection{Utility Bill Disaggregation}

Utility bill disaggregation is an analysis method that involves using information about weather and metered utility bill data to estimate end-use loads. It typically distinguishes which yearround loads are independent of space conditioning. CARB analyzed monthly electricity and gas consumption against monthly outdoor air temperatures over those utility billing periods. By examining swing season periods that had no space-conditioning loads, CARB was able to develop estimates of space-conditioning loads and non-space-conditioning loads. This monthly average was extrapolated to an annual consumption amount. Figure 12 shows annual non-spaceconditioning loads determined by the disaggregation method against actual loads measured. Even though this is a simplified analysis method, it resulted in predictions of the non-spaceconditioning uses of $4 \%-20 \%$ of actual consumption.

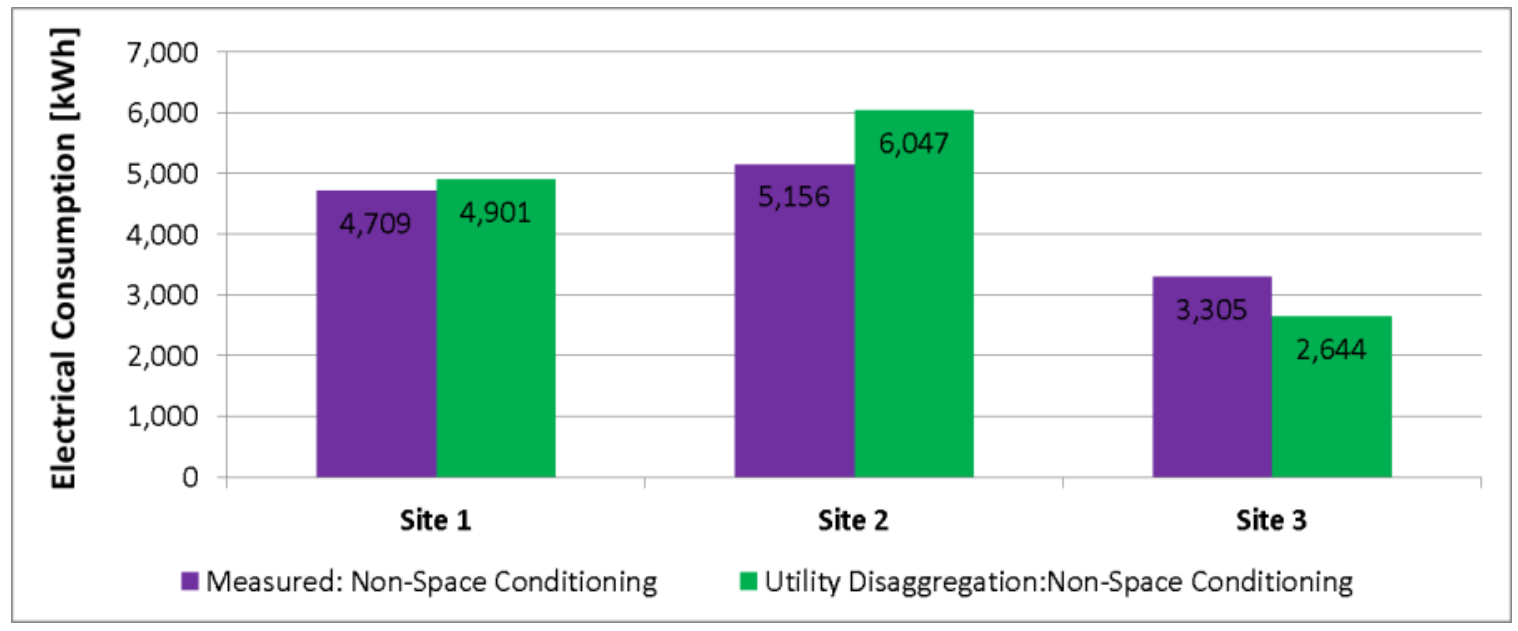

Figure 12. Utility bill disaggregation of non-space-conditioning loads

The same method was examined for space-conditioning loads. The assumption was that they could be estimated as the total load minus the average base load seen during periods without heating and cooling. Figure 13 shows a comparison of space-conditioning loads determined from the utility disaggregation method compared to actual heating and cooling electrical energy measured. The disaggregated method data are shown as total heating and cooling loads combined where Site 1 is a mix of heating and cooling energy, Site 2 loads are mostly from cooling energy (plus some fan energy from the hydro-coil unit during the heating season), and Site 3 loads are all heating energy. Again, this simplified method produced mixed results and predicted actual use within $10 \%-43 \%$. 


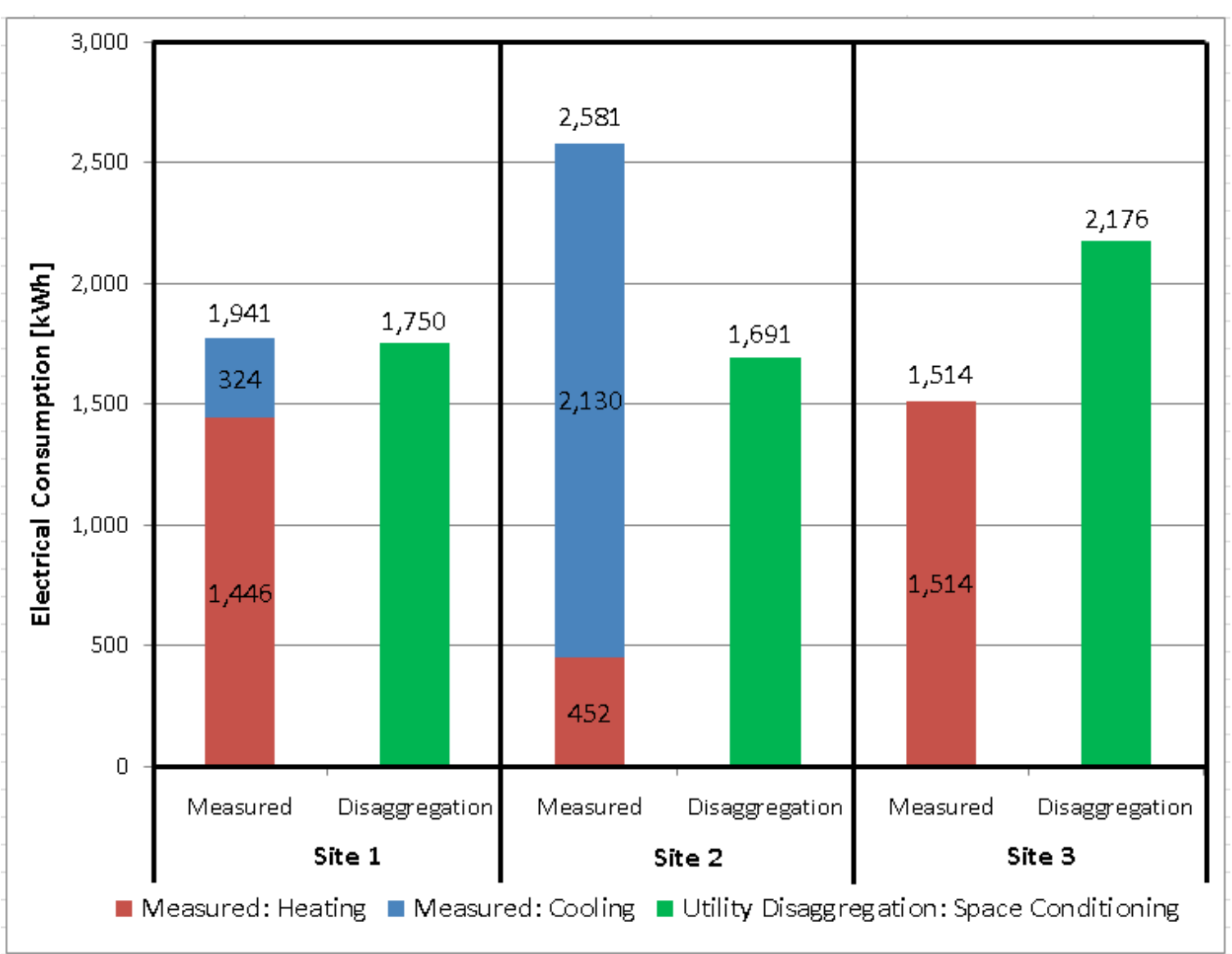

Figure 13. Utility bill disaggregation of space-conditioning loads 


\section{Discussion}

\subsection{Validating Zero Energy Ready Home Savings Claims}

Table 13 shows the difference between the actual and predicted energy consumption from the energy models (without PV generation factored in) for each of the three sites. Overall, actual energy use was generally in line with - or significantly lower than - the energy model predictions. The tuned model significantly improved accuracy at Site 3 only. This small sample size suggests that even though the individual components of the energy consumption might not be accurate the overall consumption for cold climate ZERH projects meets or exceeds the ZERH estimated energy savings mark. Based on the results from the Site 3 Passive House and past modeling experience the energy models do not accurately predict the benefits of passive solar designs.

Table 13. Site Energy: Model Prediction Compared to Actual Use (Excluding PV)

\begin{tabular}{c|c|c|c}
\hline & Site 1* & Site 2 & Site 3 \\
\hline Actual Energy Use Compared to REM/Rate Model & $6.0 \%$ & $4.5 \%$ & $-41.0 \%$ \\
\hline $\begin{array}{c}\text { Prediction } \\
\text { Actual Energy Use Compared to Base Model } \\
\quad \text { Prediction }\end{array}$ & $3.1 \%$ & $-3.0 \%$ & $-44.2 \%$ \\
\hline $\begin{array}{c}\text { Actual Energy Use Compared to Tuned Model } \\
\text { Prediction }\end{array}$ & $2.1 \%$ & $1.8 \%$ & $-32.0 \%$ \\
\hline
\end{tabular}

* Actual propane consumption for hot water use was not available for the Danbury, Connecticut, site. Because this was a minimal fraction of the total load CARB estimated use as equal to the tuned model's prediction.

\subsection{Adjusting Zero Energy Ready Home Models in BEopt}

This study indicates that several key factors should be taken into account to accurately model ZERH savings. The following sections detail the primary findings from modeling research.

\subsubsection{Lights, Appliances, and Miscellaneous Electricity Loads}

In low-load homes the percentage of electricity consumption related to LAMELs to total consumption is higher than that of a code-built home. Thus, for energy models for ZERH projects, predicting an accurate LAMELs value is crucial to overall accuracy. Unfortunately, this group of loads is difficult to predict because it is highly dependent on the occupant's variable energy use.

For a single-family home, BEopt uses the following equation to quantify miscellaneous electricity loads:

Miscellaneous electricity loads $=1185.4+180.2 \times N_{b r}+0.3188 \times F F A(\mathrm{kWh} /$ year $)$

where

$N_{b r}$ is the number of bedrooms (used to estimate occupancy)

FFA is the finished floor area of the building. 
For each site in this study LAMELs were overpredicted by the tuned model by $15 \%, 48 \%$, and $81 \%$, respectively. More research is needed to determine whether this is a consistent trend for all ZERH projects or whether it applies only to this small sample with these specific occupants. In a similar study done by the Alliance for Residential Building Innovation a retrofit turned Passive House in Sonoma, California, had $63 \%$ of the total load coming from LAMELs. The BEopt model overpredicted LAMEL consumption by $24 \%$ (German et al. 2012). The occupants of ZERHs may be more energy conscious than the typical homeowner so using a reduction multiplier for estimating miscellaneous electricity loads for ZERHs may increase the accuracy of predictions. Additional data are needed to further assess this possibility.

Table 14 shows individual electricity loads of major appliances from each site along with equations and baseline values for BA House Simulation Protocols for new-construction homes. Some appliances were not individually metered and are marked N/A. Interestingly, only refrigerator energy use is consistently higher than the House Simulation Protocols benchmark value. Clothes washer and dryer, dishwasher, and microwave uses are consistently lower. Although this data set may not be deemed statistically significant to create benchmark equations for ZERHs, it provides a comparative insight into actual consumption in occupied homes.

Table 14. Individual Appliance Loads (kWh)

\begin{tabular}{c|c|c|c|c|c|c|c|c|c}
\hline \multirow{2}{*}{$\begin{array}{c}\text { Major } \\
\text { Appliance }\end{array}$} & \multicolumn{3}{|c|}{ Site 1 } & \multicolumn{3}{c|}{ Site 2 } & \multicolumn{3}{c}{ Site 3 } \\
\cline { 2 - 12 } & Actual & Model & $\begin{array}{c}\text { \% } \\
\text { Diff. }\end{array}$ & Actual & Model & $\begin{array}{c}\% \\
\text { Diff. }\end{array}$ & Actual & Model & $\begin{array}{c}\% \\
\text { Diff. }\end{array}$ \\
\hline Washer & 25.1 & 77.5 & $209 \%$ & N/A & N/A & N/A & 18.2 & 51.7 & $184 \%$ \\
\hline Refrigerator & 564.2 & 434.0 & $-23 \%$ & 628.5 & 434.0 & $-31 \%$ & 583.9 & 434.0 & $-19 \%$ \\
\hline Dryer* & 291.1 & $1,076.4$ & $270 \%$ & 480.5 & $1,255.8$ & $161 \%$ & N/A & N/A & N/A \\
\hline Dishwasher & 154.5 & 499.0 & $223 \%$ & 75.4 & 582.0 & $672 \%$ & 6.9 & 333.0 & $4,726 \%$ \\
\hline Microwave & 88.3 & 115.4 & $31 \%$ & 30.8 & 115.4 & $275 \%$ & N/A & 115.4 & - \\
\hline Total & $1,123.2$ & $2,202.3$ & $96 \%$ & $1,215.2$ & $2,387.2$ & $96 \%$ & 609.0 & 934.1 & $53 \%$ \\
\hline
\end{tabular}

* Site 1 uses a condensing electric dryer.

\subsubsection{Space Conditioning}

Many builders use mini-split heat pumps for all-electric low-load homes. In an ongoing heat pump modeling research effort, CARB has learned that many modeling software programs do not accurately predict the consumption of mini-split heat pumps in cold climates. Figure 14 shows a comparison of the heat pump's actual average daily electricity consumption and the model's prediction at similar temperatures for Site 1. In this case the model underpredicted space-conditioning consumption by a factor of nearly 2 . More field monitoring research is needed to characterize how effectively inverter-driven mini-split heat pumps operate in cold climates. 


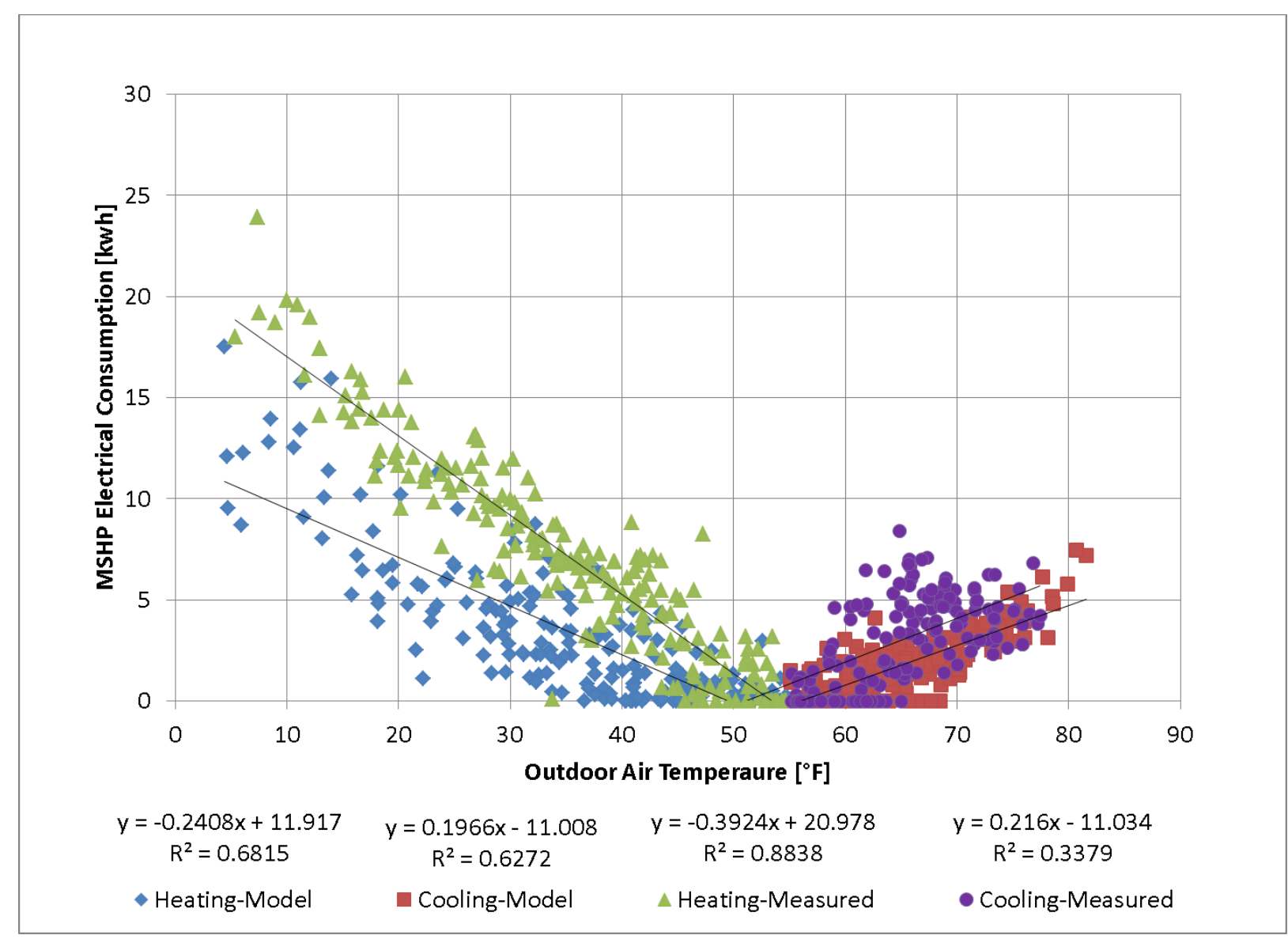

Figure 14. Site 1: Daily average mini-split heat pump consumption comparison

Site 2 used natural gas so predictions were generally in line with utility bill consumption data. The model underpredicted gas consumption by 61 therms (approximately 10\%). Utility bill disaggregation indicates that most of this underestimation stems from the occupant's high nonheating gas use.

Site 3 used a simple electric resistance heating strategy; however, heating energy use was still overestimated by $441 \mathrm{kWh}$ or approximately $41 \%$. Much of this discrepancy likely comes from unaccounted solar and internal gains in the model. For highly insulated Passive Houses, some builders assume that $50 \%$ of a building's heat will come from the sun, $25 \%$ from internal gains, and the remaining 25\% from the home's heating system (DOE 2014c). This load distribution adds a level of complexity to modeling because less of the load becomes solely dependent on outdoor air temperature. Because many ZERHs meet much of their heating load with solar and internal gains, accurately quantifying this effect becomes particularly important. 


\section{Conclusion}

To summarize this research, the research questions outlined in Section 1.2 of this report are given here with summary answers.

\section{How does actual energy use for homes built to DOE's ZERH requirements compare to predicted energy use?}

Table 15 provides a comparison summary of actual energy use in relation to energy model predictions. These values show that the actual use is generally in line with model estimates for the two non-Passive Houses $( \pm 6 \%)$ but actual use is significantly lower than model predictions for the Passive House. This suggests that actual savings are about the same as or greater than predicted by the model and that these ZERHs are certainly achieving or exceeding the targeted $40 \%$ savings mark.

Table 15. Site Energy: Model Prediction Compared to Actual Use (Excluding PV)

\begin{tabular}{c|c|c|c}
\hline & Site 1* & Site 2 & Site 3 \\
\hline $\begin{array}{c}\text { Actual Energy Use Compared to REM/Rate } \\
\text { Model Prediction }\end{array}$ & $6.0 \%$ & $4.5 \%$ & $-41.0 \%$ \\
\hline $\begin{array}{c}\text { Actual Energy Use Compared to Base } \\
\text { Model Prediction }\end{array}$ & $3.1 \%$ & $-3.0 \%$ & $-44.2 \%$ \\
\hline $\begin{array}{c}\text { Actual Energy Use Compared to Tuned } \\
\text { Model Prediction }\end{array}$ & $2.1 \%$ & $1.8 \%$ & $-32.0 \%$ \\
\hline
\end{tabular}

* Actual propane consumption data for hot water use were not available for the Danbury, Connecticut, site. Because this was a minimal fraction of the total load, CARB estimated that the use was equal to the tuned model's prediction.

REM/Rate models aligned with BEopt baseline models on the total consumption level. A more detailed analysis showed major discrepancies at the end-use level. The only trend consistent in all three sites was REM/Rate higher prediction of LAMELs. Heating, cooling, and water heating consumption alignment varied from site to site.

\section{Can any differences be explained?}

Table 16 shows that differences varied from site to site but the greatest discrepancies were consistently in the LAMEL category. Many of these discrepancies stem from the fact that LAMELs are most dependent on occupant use trends. Also, heating, cooling, and hot water loads are much lower for low-load homes so the LAMELs make up a greater percentage of total energy use. Except for the Site 1 REM/Rate model, actual measured LAMELs were 13\%-57\% less than estimated by the models.

At Site 1 with the mini-split heat pump, the BEopt model underestimated both heating and cooling consumption. REM/Rate underestimated heating consumption and overestimated cooling consumption. These discrepancies may have been caused by outdated performance curves in the modeling software. At Site 2 both modeling software packages underpredicted spaceconditioning use (heating and cooling). Because the heating electrical energy use is only for fans 
and pumps, the magnitude of monthly differences were small $-116 \mathrm{kWh} / \mathrm{month}$ on average. Cooling differences can potentially be explained by unaccounted internal gains (because LAMELs were much higher). At Site 3 with electric resistance baseboards, heating use was overpredicted by REM/Rate and underpredicted by BEopt. CARB suggests that this is likely a consequence of the load being more dependent on thermal inertia and solar and internal gains as opposed to outdoor air temperature.

Table 16. Electrical Energy Consumption Comparison Summary: Percent Difference in Site Energy Use Between Measured and Modeled

\begin{tabular}{c|c|c|c|c|c|c|c|c|c}
\hline & \multicolumn{3}{|c|}{ Site 1 } & \multicolumn{3}{c|}{ Site 2 } & \multicolumn{3}{c}{ Site 3 } \\
\hline Model: & REM/ & Base & Tuned & REM/ & Base & Tuned & REM/ & Base & Tuned \\
Heating & $98 \%$ & BEopt & BEopt & Rate & BEopt & BEopt & Rate & BEopt & BEopt \\
\hline Cooling & $-29 \%$ & $85 \%$ & $109 \%$ & $74 \%$ & $262 \%$ & $290 \%$ & $-29 \%$ & $66 \%$ & $41 \%$ \\
LAMELS & $2 \%$ & $-13 \%$ & $-13 \%$ & $-34 \%$ & $-32 \%$ & $-32 \%$ & $-45 \%$ & $-57 \%$ & $-45 \%$ \\
and DHW & & $150 \%$ & $178 \%$ & $61 \%$ & - & - & - \\
\hline Total & $10 \%$ & $4 \%$ & $4 \%$ & $-13 \%$ & $-9 \%$ & $-15 \%$ & $-41 \%$ & $-44 \%$ & $-32 \%$ \\
\hline
\end{tabular}

${ }^{\mathrm{a}}$ For Site 2 the heating fuel is natural gas so only fan energy is accounted for in this analysis.

${ }^{\mathrm{b}}$ Sites 1 and 2 are showing only LAMELs because Site 1 uses propane for DHW and Site 2 uses natural gas.

\section{Should changes be made to modeling assumptions based on these research findings?}

Comparison of modeling results to actual consumption data suggests that LAMELs were overpredicted for these ZERHs. This may have happened because the ZERH occupants may be more energy conscious than the typical homeowner. CARB evaluated whether a miscellaneous load reduction factor should be used for ZERHs; however, a larger sample size is needed to develop a meaningful figure. If known, models should be adjusted to reflect the number of occupants rather than the number of bedrooms.

Modeling methods for inverter-driven mini-split heat pumps need improvement to increase whole-building electricity consumption estimates in cold climates. To accurately model these systems in BEopt it may be appropriate to use a slightly reduced heating season performance factor input. REM/Rate currently uses mini-split performance curves that were generated from Florida Solar Energy Center field data collected from the 1970s to the 1990s (Aldrich et al. 2014). Thus, modeling predictions are not entirely reflective of today's inverter-driven technology. Also, cold climate heating energy consumption is significantly overpredicted.

For highly insulated Passive Houses, thermal inertia and internal gains add a level of complexity to modeling because less of the load becomes solely dependent on outdoor air temperature. Accounting for these differences for Site 3 resulted in a $42 \%$ difference in the total predicted design loads (Arena and Faakye 2015), which would have a direct impact on the energy consumption analysis. 


\section{References}

"2012 Zero Energy Challenge Winner." (2013) Energize Connecticut, You Tube. Accessed May 18, 2015: https://www.youtube.com/watch?v=zWLeTeX542U.

Aldrich, R.; Williamson, J.; Slattery, M.; Ringold, E. (2014). Cold-Climate Air Source Heat Pumps in New York Modeling Plan. Albany, NY: New York State Energy Research and Development Authority.

Arena, L.; Faakye, O. (2015). EcoVillage: A Net Zero Energy Ready Community. Golden, CO: National Renewable Energy Laboratory, DOE/GO-102015-4550.

http://apps1.eere.energy.gov/buildings/publications/pdfs/building america/ecovillage-net-zerocommunity.pdf.

"Building America Solutions Center." (undated ). U.S. Department of Energy. Accessed April 30, 2015: https://basc.pnnl.gov/.

DOE (2014a). “Challenge Home Case Study: AquaZephyr.” U.S. Department of Energy. PNNLSA-93080. Accessed December 8, 2014: http://energy.gov/sites/prod/files/2014/09/f18/DOE ZEH AquaZephyr 9-20-14.pdf.

DOE (2014b). "Challenge Home Case Study: BPC Green Builders New Fairfield, CT." U.S. Department of Energy. PNNL-SA-93080. Accessed April 30, 2015: http://carbswa.com/Collateral/Documents/CARB$\underline{\text { SWA/Profiles/hiawinner_bpc_greenbuilders_100213.pdf. }}$

DOE (2014c). "Challenge Home Case Study: BPC Green Builders Trolle Residence Danbury, CT.” U.S. Department of Energy. PNNL-SA-93080. Accessed December 8, 2014: http://energy.gov/sites/prod/files/2014/09/f18/DOE\%20ZEH_BPC_Green_Trolle_09-20-14.pdf.

DOE (2014d). “Challenge Home Case Study: Ithaca Neighborhood Housing Services.” U.S. Department of Energy. PNNL-SA-98673. Accessed April 30, 2015: http://energy.gov/sites/prod/files/2014/10/f18/BA ZeroEnergyReady IthacaNeighborhoodHousi ngServices 062414.pdf.

DOE (2014e). "Brookside Development.” U.S. Department of Energy. PNNL-SA-105438. Accessed April 30, 2015: http://energy.gov/sites/prod/files/2014/09/f18/DOE ZEH Brookside 09-20-14 SG.pdf.

DOE (2013a). "Challenge Home Case Study: Preferred Builders Inc.” U.S. Department of Energy. PNNL-SA-105443. Accessed December 8, 2014: http://carbswa.com/Collateral/Documents/CARB-SWA/Profiles/hiawinner_preferredbuilders_100213.pdf.

DOE (2013b). “Challenge Home Case Study: Ferguson Design \& Construction, Inc.” U.S. Department of Energy. PNNL-SA-98671. Accessed April 30, 2015: http://carbswa.com/Collateral/Documents/CARB-SWA/Profiles/hiawinner_fergusondesign_100213.pdf. 
German, A.; Weitzel, B.; Backman, C. (2012). Sonoma House: Monitoring of the First U.S. Passive House Retrofit. Golden CO: National Renewable Energy Laboratory, DOE/GO-1020123632.

Hales, D. (2014) Hood River Passive House. Golden CO: National Renewable Energy Laboratory, DOE/GO-102014-4338.

Rhodes, J.D.; Gorman, W.H.; Upshaw, C. R.; Webber, M.E. (2014). “Using BEopt (EnergyPlus) With Energy audits And Surveys To Predict Actual Residential Energy Usage. Energy and Buildings.

“Trolle Home - Danbury, CT" (2014) Energize Connecticut, You Tube. Accessed May 18, 2015 : https://www.youtube.com/watch?v=qaLMy9QfNTc.

Wilson, E.; Engebrecht Metzger, C.; Horowitz, S.; Hendron, R. (2014) 2014 Building America House Simulation Protocols. Golden CO: National Renewable Energy Laboratory, NREL/TP5500-60988.

“Zero Energy Ready Home.” (undated). U.S. Department of Energy. Accessed April 30, 2015: http://energy.gov/eere/buildings/zero-energy-ready-home. 
